\title{
Use of warfarin in long-term care: a systematic review
}

Marjorie Neidecker ${ }^{1,2}$, Aarti A Patel $^{3}$, Winnie W Nelson ${ }^{3}$ and Gregory Reardon ${ }^{1,2^{*}}$

\begin{abstract}
Background: The use of warfarin in older patients requires special consideration because of concerns with comorbidities, interacting medications, and the risk of bleeding. Several studies have suggested that warfarin may be underused or inconsistently prescribed in long-term care (LTC); no published systematic review has evaluated warfarin use for stroke prevention in this setting. This review was conducted to summarize the body of published original research regarding the use of warfarin in the LTC population.

Methods: A systematic literature search of the PubMed, Cumulative Index to Nursing and Allied Health Literature, and Cochrane Library was conducted from January 1985 to August 2010 to identify studies that reported warfarin use in LTC. Studies were grouped by (1) rates of warfarin use and prescribing patterns, (2) association of resident and institutional characteristics with warfarin prescribing, (3) prescriber attitudes and concerns about warfarin use, (4) warfarin management and monitoring, and (5) warfarin-related adverse events. Summaries of study findings and quality assessments of each study were developed.

Results: Twenty-two studies met the inclusion criteria for this review. Atrial fibrillation (AF) was the most common indication for warfarin use in LTC and use of warfarin for stroke survivors was common. Rates of warfarin use in AF were low in 5 studies, ranging from $17 \%$ to $57 \%$. These usage rates were low even among residents with high stroke risk and low bleeding risk. Scored bleeding risk had no apparent association with warfarin use in AF. In physician surveys, factors associated with not prescribing warfarin included risk of falls, dementia, short life expectancy, and history of bleeding. International normalized ratio was in the target range approximately half of the time. The combined overall rate of warfarin-related adverse events and potential events was 25.5 per 100 resident months on warfarin therapy.

Conclusions: Among residents with AF, use of warfarin and maintenance of INR levels to prevent stroke appear to be suboptimal. Among prescribers, perceived challenges associated with warfarin therapy often outweigh its benefits. Further research is needed to explicitly consider the appropriate balancing of risks and benefits in this frail patient population.
\end{abstract}

\section{Background}

Beginning in the year 2015, the greatest population increases in the United States are expected to occur among persons aged 65 years and older [1]. With increasing age, the risk for developing thromboembolic disease, including deep vein thrombosis (DVT), pulmonary embolism (PE), myocardial infarction (MI), and stroke increases correspondingly. Among stroke survivors or patients with atrial fibrillation (AF), warfarin has

\footnotetext{
* Correspondence: greardon@informagenics.com

'Informagenics, LLC, 450 W. Wilson Bridge Rd., Suite 340, Worthington, OH 43085, USA

Full list of author information is available at the end of the article
}

been used for prevention of thromboembolic stroke, although among non-cardioembolic stroke survivors without AF, antiplatelet agents are first-line therapy [2]. The use of warfarin in older patients requires special consideration because of comorbidities such as kidney disease and diabetes, the use of multiple and potentially interacting medications, and the risk of bleeding, all of which increase with age and concurrently with agerelated diseases [3-6].

A number of studies have suggested that warfarin may be underused or inconsistently prescribed in long-term care (LTC) facilities [7-13]. There are several reasons this may be the case. For one, evidence-based guidelines

\section{() Biomed Central}


are not easily developed for the LTC population, and clinical trials measuring the efficacy of warfarin are rarely performed in the LTC setting. Clinicians are thus left with incomplete evidence for generalizing study findings from non-LTC patients to older and more frail LTC residents [14]. Further, clinicians are likely to be concerned about major bleeding in older patients $[14,15]$ and consequently reluctant to prescribe warfarin when indicated.

To objectively reconcile issues of benefit and risk associated with warfarin use in LTC residents and to explore its usage in this setting, a review of the findings from empirical research conducted in this setting is warranted. The purpose of this review was to identify and summarize the body of published original research regarding the use of warfarin in LTC. Because the studies reviewed here differ in purpose, articles are grouped by the most common topics identified: (1) warfarin rates of use and prescribing patterns, (2) association of resident and/or facility characteristics with warfarin prescribing, (3) prescriber attitudes and concerns about warfarin use, (4) warfarin management and monitoring, and (5) warfarinrelated adverse events.

\section{Methods}

\section{Literature search}

Two investigators (MN and GR) conducted a systematic search of the PubMed, Cumulative Index to Nursing and Allied Health Literature (CINAHL), Cochrane Database of Systematic Reviews (CDSR), Database of Abstracts and Reviews of Effects (DARE) and National Health Service Economic Evaluation Database (NHS EED) databases (Figure 1). Title, abstract, and text searches for each database were performed for the following search terms: (anticoag* OR warfarin) AND ("long-term care" OR "nursing home"). The search was repeated in PubMed using the Medical Subject Heading $(\mathrm{MeSH})$ database search key words "nursing home" and "long-term care." Additionally, the websites of the Agency for Healthcare Research and Quality (AHRQ) and the American Medical Directors Association (AMDA) were searched. A manual review of references from each pertinent article, review articles, and treatment guidelines was also conducted to identify additional related articles.

\section{Study selection}

Two investigators (MN and GR) independently determined study eligibility, with disagreement resolved by discussion. A study was deemed eligible for inclusion in the systematic review if it: (1) reported on prescribing or use of warfarin alone or in combination with antiplatelet medications in the LTC setting, (2) was published in English, (3) was published between January 1985 and August 2010, and (4) reported original research. Editorials, letters, commentaries, reviews, expert opinions or clinical topic discussions, guidelines, and case studies were excluded from this review.

\section{Data abstraction}

For each included study, data were independently abstracted by two investigators ( $\mathrm{MN}$ and GR) to include the following details: study objective, intervention/exposure and outcomes, study design, data source, study population, study setting, time period, summary of results, funding source, and quality assessment.

\section{Quality assessment}

Two investigators (MN and GR) compiled lists of strengths and weaknesses in the methodology of each study upon the initial reading. Using the quality assessment methodology for observational studies and randomized controlled trials developed by Williams et al. for the AHRQ [16], one investigator (GR) responded to the 11 structured closedended questions regarding quality for each observational study and the 10 structured closed-ended questions for the single randomized controlled trial reviewed.

\section{Results}

\section{Study identification and characteristics}

The initial search of the four electronic databases returned 273 citations, of which 41 were duplicates, leaving 232 citations for abstract and full text review. Upon review, 210 of these were excluded for failing to meet all study selection criteria. Thus, a total of 22 studies [7-13,17-31] were retained. These included: one randomized controlled trial [20]; 10 retrospective cohort studies $[8,10,11,18,19,21-23,25,30]$, one mixed prospective and retrospective cohort study [24], three case-control studies $[7,26,31]$, and seven cross-sectional studies [9,12,13,17,27-29].

Across all 22 studies, the total number of LTC residents studied was 130,757 , with sample sizes in individual studies ranging from 37 [31] to 53,829 [12]. Study duration ranged from 1 month [9] to 6 years [26]. Among the included studies, 14 reported on the rate of warfarin prevalence and prescribing patterns [7-13,17-21,24,25], eight evaluated the association of resident or facility characteristics with warfarin prescribing $[7,8,10-13,17,18]$, three reported on prescriber attitudes and concerns regarding warfarin use [27-29], nine discussed warfarin management and monitoring $[8,9,11,22-25,30,31]$, and two reported on warfarin-related adverse events [25,26]. Unless otherwise indicated below, significance was reported at $95 \%$ confidence.

\section{Rate of warfarin use and prescribing patterns}

Of the 14 studies $(112,754$ total residents) that examined the rate of warfarin use or prescribing patterns in LTC 


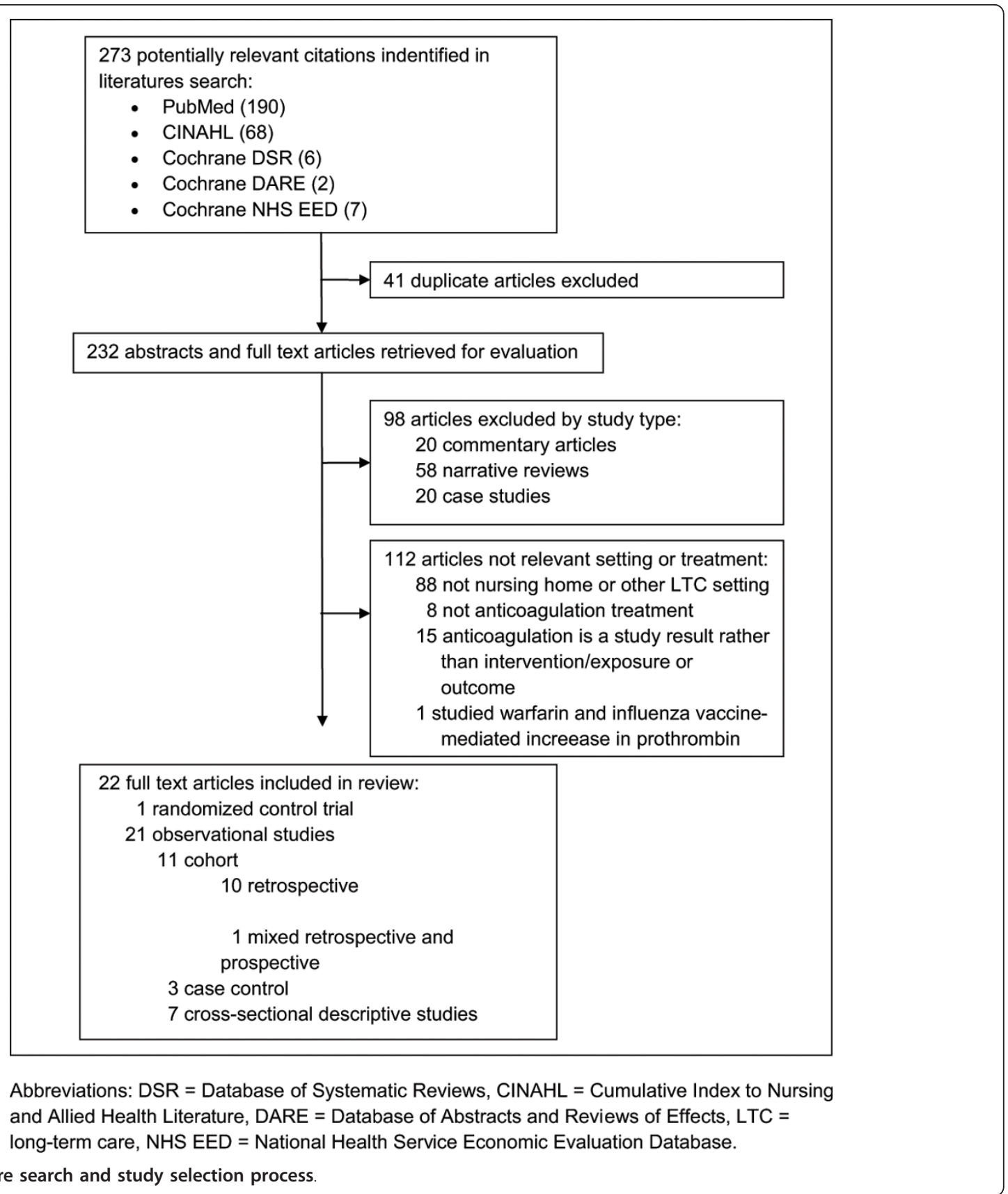

facilities, 11 (Table 1 Part A) [7-13,17-19,25] examined residents with various conditions for which warfarin is indicated, comparing residents who were prescribed warfarin with those who were not prescribed warfarin. Three of these studies [20,21,24] examined consultant pharmacist interventions with regard to warfarin prescribing in the facilities studied (Table 1 Part B).

Primary indications for warfarin therapy

AF was the primary indication for warfarin therapy in two studies $(\mathrm{n}=618$ ), accounting for $74 \%$ [24] and 58\% [25] of residents receiving warfarin, respectively. Stroke prevention without AF accounted for 12\% [25], while DVT accounted for 20\% [24], PE for 6\% [24], and either DVT or PE for 26\% [25] of residents receiving warfarin.

\section{Rate of warfarin use}

Eight studies $(n=22,573)[7-13,19]$ reported rates of warfarin use across all residents having a condition for which warfarin was indicated. These only included residents having AF or previous stroke; no other indications were described. Four of these studies $(n=2396)[7,10,12,13]$ also reported the rates of use for warfarin combined with antiplatelet therapy. Rates for warfarin use alone ranged 
Table 1 Warfarin indications, rate of use and prescribing patterns

\begin{tabular}{|c|c|c|c|c|c|}
\hline Study & $\begin{array}{l}\text { Study objective, } \\
\text { (intervention/ } \\
\text { exposure and } \\
\text { outcomes) }\end{array}$ & $\begin{array}{l}\text { Study design, } \\
\text { data source }\end{array}$ & $\begin{array}{l}\text { Study population, study } \\
\text { setting, time period }\end{array}$ & Results & Quality assessment, funding source \\
\hline \multicolumn{6}{|c|}{ Part A: Warfarin exposure } \\
\hline $\begin{array}{l}\text { Abdel-Latif et } \\
\text { al. (2005) [7] }\end{array}$ & $\begin{array}{l}\text { To determine } \\
\text { predictors of OAC } \\
\text { therapy for AF in LTC }\end{array}$ & $\begin{array}{l}\text { Design: case } \\
\text { control study } \\
\text { Data source: } \\
\text { medical chart, } \\
\text { pharmacy record, } \\
\text { and MDS }\end{array}$ & $\begin{array}{l}\text { Population: } 117 \text { residents } \\
\text { with chronic or } \\
\text { paroxysmal AF identified } \\
\text { from } 934 \text { total residents } \\
\text { Setting: } 6 \text { LTC facilities } \\
\text { with > } 100 \text { beds in } \\
\text { Cleveland metropolitan } \\
\text { area (US) } \\
\text { Time period: not specified }\end{array}$ & $\begin{array}{l}\text { Among } 117 \text { residents (12.5\% of 934) with AF, OAC } \\
\text { was prescribed for } 46 \% \text {; aspirin or clopidogrel: } 40 \% \text {; } \\
\text { no antithrombotic treatment: } 21 \% \text {. } \\
\text { Logistic regression produced } 2 \text { independent } \\
\text { predictors of OAC prescription: (1) Prior stroke was } \\
\text { the primary determinant of receiving OAC (OR = } 0.02 \text {; } \\
95 \% \mathrm{Cl}=0.09-0.47 \text { ) sic, and (2) history of Gl bleeding } \\
\text { was a predictor for not receiving OAC (OR, } 5.6 ; 95 \% \mathrm{Cl} \\
=1.1-29.4 \text { ). Classification and regression tree analysis } \\
\text { found residents with prior stroke or Gl bleeding and } \\
\text { no history of coronary artery disease and who were } \\
\text { non-Caucasian were less likely to be prescribed OAC. } \\
\text { Those without stroke were less likely to be prescribed } \\
\text { OAC if they were younger, had dementia or lower } \\
\text { functional status }\end{array}$ & $\begin{array}{l}\text { Quality assessment for observational studies: } \\
\text { 1) Unbiased selection of the cohort? Yes } \\
\text { 2) Selection minimizes baseline differences in } \\
\text { prognostic factors? Yes } \\
\text { 3) Sample size calculated/5\% difference? No } \\
\text { 4) Adequate description of the cohort? Yes } \\
\text { 5) Validated method for ascertaining exposure? Yes } \\
\text { 6) Validated method for ascertaining clinical } \\
\text { outcomes? Yes } \\
\text { 7) Outcome assessment blind to exposure? Yes } \\
\text { 8) Adequate follow-up period? Yes; date of study not } \\
\text { specified; cross-sectional } \\
\text { 9) Completeness of follow-up? Yes } \\
\text { 10) Analysis controls for confounding? Yes } \\
\text { 11) Analytic methods appropriate? Partial; MDS } \\
\text { cognition and functional scale scoring methods not } \\
\text { referenced; multivariate findings not fully reported } \\
\text { Funding: not specified }\end{array}$ \\
\hline $\begin{array}{l}\text { Christian et } \\
\text { al. (2003) [17] }\end{array}$ & $\begin{array}{l}\text { To evaluate the } \\
\text { extent to which } \\
\text { people of color (e.g. } \\
\text { non-white or } \\
\text { Hispanic) in US } \\
\text { nursing homes were } \\
\text { less likely to receive } \\
\text { pharmacologic } \\
\text { treatment of recurrent } \\
\text { stroke }\end{array}$ & $\begin{array}{l}\text { Design: } \\
\text { retrospective } \\
\text { cross-sectional } \\
\text { study } \\
\text { Data source: the } \\
\text { SAGE database } \\
\text { (links inpatient } \\
\text { Medicare claims, } \\
\text { drug data, and } \\
\text { MDS data) }\end{array}$ & $\begin{array}{l}\text { Population: } 19,051 \\
\text { nursing home residents } \\
\text { with recent } \\
\text { hospitalization for } \\
\text { ischemic stroke } \\
\text { Setting: Kansas, Maine, } \\
\text { Mississippi, Ohio, New } \\
\text { York, and South Dakota } \\
\text { (US) } \\
\text { Time period: 1992-1996 }\end{array}$ & $\begin{array}{l}\text { Variability in use of any treatment for secondary } \\
\text { stroke prevention (warfarin or antiplatelet agent) was } \\
\text { observed by race/ethnicity: } 58 \% \text { of American Indians } \\
\text { received therapy, } 54 \% \text { of non-Hispanic whites, } 49 \% \text { of } \\
\text { non-Hispanic blacks, } 46 \% \text { of Hispanics, and only } 39 \% \\
\text { of Asian/Pacific Islanders. } \\
\text { The use of warfarin among residents with conditions } \\
\text { warranting anticoagulant therapy was } 40 \% \text { among } \\
\text { non-Hispanic whites, } 36 \% \text { among American Indians, } \\
32 \% \text { among non-Hispanic blacks, } 26 \% \text { of Asian/Pacific } \\
\text { Islanders, and } 25 \% \text { among Hispanics. After controlling } \\
\text { for confounding, Asian/Pacific Islanders (prevalence } \\
\text { difference }=-5.2, \mathrm{Cl}=-18.1 \text { to } 7.8 \text { ), non-Hispanic black } \\
\text { residents (prevalence difference =-7.6, Cl= }-11.2 \text { to } \\
-3.9 \text { ), and Hispanics (prevalence difference }=-7.6, \mathrm{Cl}= \\
-17.6 \text { to } 2.2 \text { received warfarin less often than non- } \\
\text { Hispanic whites }\end{array}$ & $\begin{array}{l}\text { Quality assessment for observational studies: } \\
\text { 1) Unbiased selection of the cohort? Yes } \\
\text { 2) Selection minimizes baseline differences in } \\
\text { prognostic factors? Yes } \\
\text { 3) Sample size calculated/5\% difference? Partial; likely } \\
\text { lacked statistical power for Asian/Pacific Islanders, } \\
\text { Hispanics, and American Indians } \\
\text { 4) Adequate description of the cohort? Yes } \\
\text { 5) Validated method for ascertaining exposure? Yes } \\
\text { 6) Validated method for ascertaining clinical } \\
\text { outcomes? Yes } \\
\text { 7) Outcome assessment blind to exposure? Yes } \\
\text { 8) Adequate follow-up period? No; uses data from } \\
\text { admission only so secondary stroke prevention was } \\
\text { more likely ordered at hospital discharge, not in LTC } \\
\text { facility } \\
\text { 9) Completeness of follow-up? No } \\
\text { 10) Analysis controls for confounding? Yes } \\
\text { 11) Analytic methods appropriate? Partial; prevalence } \\
\text { differences reported rather than association strength } \\
\text { (i.e. no OR) } \\
\text { Funding: National Institute on Aging, AHRQ }\end{array}$ \\
\hline
\end{tabular}


Table 1 Warfarin indications, rate of use and prescribing patterns (Continued)

\begin{tabular}{|c|c|c|c|c|c|}
\hline $\begin{array}{l}\text { Gurwitz et al. } \\
\text { (2007) [25] }\end{array}$ & $\begin{array}{l}\text { To examine the } \\
\text { preventability of } \\
\text { actual and potential } \\
\text { warfarin-related } \\
\text { adverse events in the } \\
\text { nursing home setting }\end{array}$ & $\begin{array}{l}\text { Design: } \\
\text { retrospective } \\
\text { cohort study } \\
\text { Data source: } \\
\text { nursing home } \\
\text { records }\end{array}$ & $\begin{array}{l}\text { Population: all } 490 \\
\text { residents of } 25 \text { nursing } \\
\text { homes receiving warfarin } \\
\text { therapy } \\
\text { Setting: } 25 \text { nursing homes } \\
\text { (bed size range, 90-360) } \\
\text { in Connecticut (US) } \\
\text { Time period: } 12 \text { - month } \\
\text { observation period (Apr } \\
2003 \text { - Mar 2004) }\end{array}$ & $\begin{array}{l}\text { The most common indications for warfarin therapy } \\
\text { included stroke prevention in AF (58\%), treatment/ } \\
\text { prevention of DVT or PE (26\%), and stroke prevention } \\
\text { without AF (12\%) }\end{array}$ & $\begin{array}{l}\text { Quality assessment for observational studies: } \\
\text { 1) Unbiased selection of the cohort? Yes } \\
\text { 2) Selection minimizes baseline differences in } \\
\text { prognostic factors? Yes } \\
\text { 3) Sample size calculated/5\% difference? Yes } \\
\text { 4) Adequate description of the cohort? Yes } \\
\text { 5) Validated method for ascertaining exposure? Partial; } \\
\text { classification of warfarin use/non-use within a given } \\
\text { resident-month not explicated } \\
\text { 6) Validated method for ascertaining clinical } \\
\text { outcomes? Yes } \\
\text { 7) Outcome assessment blind to exposure? Yes } \\
\text { 8) Adequate follow-up period? Yes } \\
\text { 9) Completeness of follow-up? Yes } \\
\text { 10) Analysis controls for confounding? No; Did not } \\
\text { analyze prognostic factors associated with adverse } \\
\text { warfarin-related events other than warfarin exposure } \\
\text { 11) Analytic methods appropriate? Partial; association } \\
\text { of resident characteristics or INR values with risk of } \\
\text { adverse warfarin-related event not assessed } \\
\text { Funding: AHRQ }\end{array}$ \\
\hline $\begin{array}{l}\text { Gurwitz et al. } \\
\text { (1997) [8] }\end{array}$ & $\begin{array}{l}\text { To determine the } \\
\text { prevalence of AF in } \\
\text { the institutionalized } \\
\text { elderly population } \\
\text { and the proportion } \\
\text { receiving warfarin; to } \\
\text { identify clinical and } \\
\text { functional } \\
\text { characteristics of } \\
\text { institutionalized } \\
\text { elderly persons with } \\
\text { AF that are associated } \\
\text { with the use of } \\
\text { warfarin; access } \\
\text { quality of warfarin } \\
\text { prescribing and } \\
\text { monitoring }\end{array}$ & $\begin{array}{l}\text { Design: } \\
\text { retrospective } \\
\text { cohort study } \\
\text { Data source: } \\
\text { medical record } \\
\text { review of } \\
\text { residents with } \geq 2 \\
\text { weeks of warfarin } \\
\text { therapy during } \\
\text { the } 12 \text {-month } \\
\text { period preceding } \\
\text { the date of } \\
\text { medical record } \\
\text { abstraction }\end{array}$ & $\begin{array}{l}\text { Population: } 6437 \text { residents } \\
\text { of LTC facilities } \\
\text { Setting: } 30 \text { LTC facilities } \\
\text { (6437 total number of } \\
\text { beds) located in New } \\
\text { England, Quebec, and } \\
\text { Ontario (US and Canada) } \\
\text { Time period: Jul 1993-Aug } \\
1995\end{array}$ & $\begin{array}{l}\text { An electrocardiogram indicating AF was present in } \\
\text { the records of } 7.5 \% \text { of } 5500 \mathrm{LTC} \text { residents; } 32 \% \text { of } \\
\text { such patients were being treated with warfarin. In } \\
\text { multivariate analysis, only a history of stroke }(\mathrm{OR}= \\
1.87 ; 95 \% \mathrm{Cl}=1.20-2.91) \text { was found to be positively } \\
\text { associated with the use of warfarin in this setting. } \\
\text { Patients with a diagnosis of dementia (OR }=0.59 ; 95 \% \\
\mathrm{Cl}=0.38-0.90) \text { and those aged_85 years }(\mathrm{OR}=0.46 \text {; } \\
95 \% \mathrm{Cl}=0.22-0.94) \text { were less likely to receive warfarin } \\
\text { therapy. Warfarin was commonly prescribed to } \\
\text { patients with a history of bleeding ( } 28.5 \%) \text {, substantial } \\
\text { co-morbidity ( } 30.8 \% \text { major) and functional impairment } \\
\text { (25.4\% severe), a history of falls ( } 28.5 \%) \text {, or } \\
\text { concomitant potentiating drug therapy (17.7\%) }\end{array}$ & $\begin{array}{l}\text { Quality assessment for observational studies: } \\
\text { 1) Unbiased selection of the cohort? Yes } \\
\text { 2) Selection minimizes baseline differences in } \\
\text { prognostic factors? Yes } \\
\text { 3) Sample size calculated/5\% difference? Yes } \\
\text { 4) Adequate description of the cohort? Yes } \\
\text { 5) Validated method for ascertaining exposure? Yes } \\
\text { 6) Validated method for ascertaining clinical } \\
\text { outcomes? Yes } \\
\text { 7) Outcome assessment blind to exposure? Yes } \\
\text { 8) Adequate follow-up period? Yes (cross-sectional) } \\
\text { 9) Completeness of follow-up? Yes } \\
\text { 10) Analysis controls for confounding? Yes } \\
\text { 11) Analytic methods appropriate? Yes } \\
\text { Funding: DuPont Pharma, the National Institute on } \\
\text { Aging, Medical Research Council of the Province of } \\
\text { Quebec }\end{array}$ \\
\hline
\end{tabular}


Table 1 Warfarin indications, rate of use and prescribing patterns (Continued)

\begin{tabular}{|c|c|c|c|c|c|}
\hline $\begin{array}{l}\text { Hughes et al. } \\
\text { (2004) [18] }\end{array}$ & $\begin{array}{l}\text { To identify factors } \\
\text { relating to initiation } \\
\text { and discontinuation } \\
\text { of secondary stroke } \\
\text { prevention agents } \\
\text { (warfarin and } \\
\text { antiplatelets) among } \\
\text { stroke survivors in } \\
\text { nursing homes. }\end{array}$ & $\begin{array}{l}\text { Design: } \\
\text { retrospective } \\
\text { cohort study } \\
\text { Data source: MDS } \\
\text { for patient } \\
\text { characteristics } \\
\text { matched to the } \\
\text { OSCAR system for } \\
\text { facility } \\
\text { characteristics }\end{array}$ & $\begin{array}{l}\text { Population: } 16,579 \text { stroke } \\
\text { survivors; } 9547 \text { were not } \\
\text { receiving any secondary } \\
\text { stroke prevention } \\
\text { treatment at admission; } \\
6244 \text { were receiving } \\
\text { therapy } \\
\text { Setting: nursing homes in } \\
6 \text { states (US) } \\
\text { Time period: } \\
\text { 1992-1996: each resident } \\
\text { was followed } \geq 6 \text { months }\end{array}$ & $\begin{array}{l}\text { In all, } 12 \% \text { initiated drug therapy (warfarin or } \\
\text { antiplatelet); } 30.3 \% \text { discontinued. Conditions known to } \\
\text { increase the risk of recurrent stroke (e.g. AF) were } \\
\text { predictive of initiation. Factors inversely related to } \\
\text { initiation of therapy included advanced age, severe } \\
\text { cognitive impairment, and being dependent in ADLs. } \\
\text { Co-morbid conditions were inversely related to } \\
\text { discontinuation of treatment, whereas advanced age } \\
\text { and severe cognitive impairment increased likelihood } \\
\text { of discontinuation. } \\
\text { Black residents (OR }=0.62 ; 95 \% \mathrm{Cl}=0.49-0.78 \text { ) were } \\
\text { less likely than non- Hispanic white residents to } \\
\text { initiate therapy. Asian/Pacific Islanders (OR }=0.44 ; 95 \% \\
\mathrm{Cl}=0.23-0.83 \text { ) were less likely than non-Hispanic } \\
\text { white residents to discontinue therapy }\end{array}$ & $\begin{array}{l}\text { Quality assessment: for observational studies: } \\
\text { 1) Unbiased selection of the cohort? Yes } \\
\text { 2) Selection minimizes baseline differences in } \\
\text { prognostic factors? Yes } \\
\text { 3) Sample size calculated/5\% difference? Yes } \\
\text { 4) Adequate description of the cohort? Yes } \\
\text { 5) Validated method for ascertaining exposure? Yes } \\
\text { 6) Validated method for ascertaining clinical } \\
\text { outcomes? Yes } \\
\text { 7) Outcome assessment blind to exposure? Yes } \\
\text { 8) Adequate follow-up period? Partial; range of follow- } \\
\text { up for observing initiation/discontinuation events was } \\
\text { 6-13 months } \\
\text { 9) Completeness of follow-up? Yes } \\
\text { 10) Analysis controls for confounding? Partial; length } \\
\text { of follow-up not treated as a covariate in adjusted } \\
\text { logistic regression models } \\
\text { 11) Analytic methods appropriate? Yes } \\
\text { Funding: National Institute on Aging }\end{array}$ \\
\hline $\begin{array}{l}\text { Lackner et al. } \\
\text { (1995) [9] }\end{array}$ & $\begin{array}{l}\text { To assess warfarin use } \\
\text { and monitoring in } \\
\text { nursing home } \\
\text { patients with NVAF, } \\
\text { according to } \\
\text { American College of } \\
\text { Chest Physicians } \\
\text { Consensus } \\
\text { Conference guidelines }\end{array}$ & $\begin{array}{l}\text { Design: } \\
\text { retrospective, } \\
\text { cross-sectional } \\
\text { study } \\
\text { Data source: } \\
\text { medical record } \\
\text { review and } \\
\text { attending } \\
\text { physician } \\
\text { response to } \\
\text { written } \\
\text { communication } \\
\text { from the nursing } \\
\text { home's medical } \\
\text { director and } \\
\text { consultant } \\
\text { pharmacist }\end{array}$ & $\begin{array}{l}\text { Population: } 902 \text { patients } \\
\text { aged } \geq 60 \text { years, from } \\
\text { whom } 69 \text { with a } \\
\text { diagnosis of NVAF and } 16 \\
\text { with VAF (control group) } \\
\text { were identified } \\
\text { Setting: } 5 \text { nursing homes } \\
\text { in Minneapolis-St Paul, } \\
\text { Minn (US) } \\
\text { Time period: 1-month } \\
\text { period (June 1993) }\end{array}$ & $\begin{array}{l}\text { NVAF was documented in } 7.6 \% \text { and VAF in } 1.8 \% \text { of } \\
\text { the patients. Only } 17 \% \text { of patients with NVAF were } \\
\text { receiving warfarin, compared to } 31 \% \text { of patients with } \\
\text { VAF. } 58 \% \text { of patients with NVAF and without a } \\
\text { conventional contraindication to warfarin had } \geq 1 \text { risk } \\
\text { factor for thromboembolism in addition to AF and } \\
\text { advanced age, yet only } 20 \% \text { used warfarin }\end{array}$ & $\begin{array}{l}\text { Quality assessment for observational studies: } \\
\text { 1) Unbiased selection of the cohort? Yes } \\
\text { 2) Selection minimizes baseline differences in } \\
\text { prognostic factors? Yes } \\
\text { 3) Sample size calculated/5\% difference? No; low } \\
\text { power } \\
\text { 4) Adequate description of the cohort? Yes } \\
\text { 5) Validated method for ascertaining exposure? Yes } \\
\text { 6) Validated method for ascertaining clinical } \\
\text { outcomes? } \\
\text { Yes } \\
\text { 7) Outcome assessment blind to exposure? Yes } \\
\text { 8) Adequate follow-up period? Yes (cross-sectional) } \\
\text { 9) Completeness of follow-up? Yes } \\
\text { 10) Analysis controls for confounding? Partial; } \\
\text { evaluated univariate association of stroke risk factors } \\
\text { and warfarin contraindications with warfarin use } \\
\text { 11) Analytic methods appropriate? Partial; Cls not } \\
\text { included in any findings } \\
\text { Funding: Dupont Pharmaceuticals }\end{array}$ \\
\hline
\end{tabular}


Table 1 Warfarin indications, rate of use and prescribing patterns (Continued)

\begin{tabular}{|c|c|c|c|c|c|}
\hline $\begin{array}{l}\text { Lapane et al. } \\
\text { (2006) [19] }\end{array}$ & $\begin{array}{l}\text { To evaluate the } \\
\text { impact of the } \\
\text { implementation of } \\
\text { the Medicare PPS on } \\
\text { pharmacologic } \\
\text { secondary ischemic } \\
\text { stroke prevention } \\
\text { (standing orders for } \\
\text { antiplatelets or } \\
\text { warfarin) in nursing } \\
\text { homes }\end{array}$ & $\begin{array}{l}\text { Design: } \\
\text { retrospective } \\
\text { cohort study } \\
\text { Data source: the } \\
\text { SAGE database } \\
\text { (including MDS } \\
\text { data and all drugs } \\
\text { taken } 7 \text { days } \\
\text { preceding MDS } \\
\text { assessment) }\end{array}$ & $\begin{array}{l}\text { Population: residents who } \\
\text { were hospitalized with an } \\
\text { ischemic stroke within } 6 \\
\text { months (1997, } n=5008 ; \\
\text { 2000, } n=5243 \text { ) of living } \\
\text { in nursing facilities } \\
\text { Setting: nursing facilities } \\
\text { in Kansas, Maine, } \\
\text { Mississippi, or Ohio (1997: } \\
n=1226 ; \text { 2000: } n= \\
\text { 1092) (US) } \\
\text { Time period: Pre- PPS } \\
\text { period = 1997; post-PPS } \\
\text { period = 2000 }\end{array}$ & $\begin{array}{l}\text { The unadjusted proportion of use of pharmacologic } \\
\text { agents for the secondary prevention of stroke was } \\
\text { similar for warfarin in both time periods (1997: 22.9\%; } \\
\text { 2000: } 22.4 \% \text { ) and increased for antiplatelets } \\
(1997: 40.8 \% ; 2000: 47.7 \%) \text {, as a result of the } \\
\text { introduction of clopidogrel. Among residents with } \\
\text { conditions indicating the use of warfarin, after } \\
\text { adjusting for resident and facility characteristics, the } \\
\text { likelihood of use of antiplatelets increased in the post- } \\
\text { PPS era (adjusted OR }=1.26 ; 95 \% \mathrm{Cl}=1.15-1.38 \text { ); the } \\
\text { likelihood of use of the use of warfarin did not } \\
\text { change (adjusted OR }=0.99 ; 95 \% \mathrm{Cl}=0.86-1.14 \text { ) }\end{array}$ & $\begin{array}{l}\text { Quality assessment for observational studies: } \\
\text { 1) Unbiased selection of the cohort? Yes } \\
\text { 2) Selection minimizes baseline differences in } \\
\text { prognostic factors? Partial; design does control for } \\
\text { effects of history other than implementation of PPS } \\
\text { between pre- and post-PPS period (e.g. issuance of } \\
\text { prescribing guidelines) } \\
\text { 3) Sample size calculated/5\% } \\
\text { difference? Yes } \\
\text { 4) Adequate description of the cohort? Yes } \\
\text { 5) Validated method for ascertaining exposure? Yes } \\
\text { 6) Validated method for ascertaining clinical } \\
\text { outcomes? Yes } \\
\text { 7) Outcome assessment blind to exposure? Yes } \\
\text { 8) Adequate follow-up period? Partial; evaluated only } \\
\text { 1 pre- and post-PPS year; cross-sectional } \\
\text { 9) Completeness of follow-up? Yes } \\
\text { 10) Analysis controls for confounding? Yes } \\
\text { 11) Analytic methods appropriate? Yes } \\
\text { Funding: supported by a National Primary Care Career } \\
\text { Scientist Award from the Research and Development } \\
\text { Office, Northern Ireland }\end{array}$ \\
\hline $\begin{array}{l}\text { Lau et al. } \\
\text { (2004) [10] }\end{array}$ & $\begin{array}{l}\text { To identify patterns } \\
\text { and predictors of } \\
\text { antithrombotic use } \\
\text { and to evaluate the } \\
\text { appropriateness of } \\
\text { antithrombotic } \\
\text { therapy for stroke } \\
\text { prophylaxis in } \\
\text { institutionalized } \\
\text { elderly patients with } \\
\text { AF }\end{array}$ & $\begin{array}{l}\text { Design: } \\
\text { retrospective } \\
\text { cohort study } \\
\text { Data source: } \\
\text { Administrative } \\
\text { databases and } \\
\text { medical records }\end{array}$ & $\begin{array}{l}\text { Population: } 265 \text { LTC } \\
\text { residents, aged } \geq 65 \text { and } \\
\text { older, with AF } \\
\text { Setting: } 17 \text { LTC } \\
\text { institutions in Edmonton, } \\
\text { Alberta (Canada) } \\
\text { Time period: Nov } 2001 \text { - } \\
\text { Feb } 2002\end{array}$ & $\begin{array}{l}\text { Warfarin was prescribed for } 49 \% \text { of patients, aspirin } \\
\text { for } 22 \% \text {, both for } 8 \% \text {, and neither for } 20 \% \text {. Nearly all } \\
\text { patients }(97 \%) \text { were considered to be at high risk for } \\
\text { stroke, with age being the predominant risk factor } \\
(88 \% \geq 75 \text { years), whereas about half ( } 54 \% \text { ) were } \\
\text { considered to be at low risk for bleeding. Multivariate } \\
\text { analyses found no associations between individual risk } \\
\text { factors for bleeding and anticoagulation treatment, } \\
\text { with the exception of recent surgery (OR }=0.59 ; 95 \% \\
\mathrm{Cl}=0.37-0.94) \text {. Overall, } 54.8 \% \text { of patients received } \\
\text { appropriate antithrombotic therapy congruent with } \\
\text { stroke and bleeding. Of patients who were optimal } \\
\text { candidates for anticoagulation, } 60 \% \text { received } \\
\text { appropriate therapy (warfarin with or without aspirin) }\end{array}$ & $\begin{array}{l}\text { Quality assessment for observational studies: } \\
\text { 1) Unbiased selection of the cohort? Yes } \\
\text { 2) Selection minimizes baseline differences in } \\
\text { prognostic factors? Yes } \\
\text { 3) Sample size calculated/5\% difference? Yes } \\
\text { 4) Adequate description of the cohort? Yes } \\
\text { 5) Validated method for ascertaining exposure? Partial; } \\
\text { unlike stroke risk, categorization by bleeding risk not } \\
\text { based on validated algorithm or consensus guideline } \\
\text { 6) Validated method for ascertaining clinical } \\
\text { outcomes? Yes } \\
\text { 7) Outcome assessment blind to exposure? Yes } \\
\text { 8) Adequate follow-up period? Yes; cross-sectional } \\
\text { 9) Completeness of follow-up? Yes } \\
\text { 10) Analysis controls for confounding? Yes } \\
\text { 11) Analytic methods appropriate? Yes } \\
\text { Funding: not specified }\end{array}$ \\
\hline
\end{tabular}


Table 1 Warfarin indications, rate of use and prescribing patterns (Continued)

\begin{tabular}{|c|c|c|c|c|c|}
\hline $\begin{array}{l}\text { McCormick } \\
\text { et al. (2001) } \\
\text { [11] }\end{array}$ & $\begin{array}{l}\text { To assess: (1) the } \\
\text { prevalence of AF and } \\
\text { the percentage of AF } \\
\text { patients who receive } \\
\text { therapy with warfarin } \\
\text { or aspirin, (2) the } \\
\text { relationship between } \\
\text { the presence of } \\
\text { known risk factors for } \\
\text { stroke and bleeding } \\
\text { among persons with } \\
\text { AF and their receipt } \\
\text { of warfarin, and (3) } \\
\text { the quality of warfarin } \\
\text { prescribing and } \\
\text { monitoring in nursing } \\
\text { home residents with } \\
\text { AF }\end{array}$ & $\begin{array}{l}\text { Design: } \\
\text { retrospective } \\
\text { cohort study } \\
\text { Data source: } \\
\text { Medical record } \\
\text { review }\end{array}$ & $\begin{array}{l}\text { Population: } 2587 \text { LTC } \\
\text { residents } \\
\text { Setting: } 21 \text { LTC facilities in } \\
\text { Connecticut (US) } \\
\text { Time period: 1997-1998 } \\
\end{array}$ & $\begin{array}{l}\text { AF was present in } 17 \% \text { of LTC residents, risk factors } \\
\text { for stroke in } 93 \% \text { of AF residents, and for bleeding in } \\
80 \% \text { of AF residents. Overall, } 42 \% \text { of AF patients were } \\
\text { receiving warfarin. However, of } 83 \text { ideal candidates, } \\
\text { only } 53 \% \text { were receiving this therapy. The odds of } \\
\text { receiving warfarin in the study sample decreased with } \\
\text { increasing number of risk factors for bleeding } \\
\text { (adjusted OR for }>1 \text { bleeding risk factor compared to } \\
\text { none: } 0.51 ; \mathrm{Cl}, 0.29-0.94 \text { ) and increased (non- } \\
\text { significant trend) with increasing number of stroke } \\
\text { risk factors }\end{array}$ & $\begin{array}{l}\text { Quality assessment for observational studies: } \\
\text { 1) Unbiased selection of the cohort? Yes } \\
\text { 2) Selection minimizes baseline differences in } \\
\text { prognostic factors? Yes } \\
\text { 3) Sample size calculated/5\% difference? Yes } \\
\text { 4) Adequate description of the cohort? Yes } \\
\text { 5) Validated method for ascertaining exposure? No; } \\
\text { stroke risk and bleeding risk classification not } \\
\text { adequately described (i.e. no reference to validated } \\
\text { algorithm or consensus guideline) } \\
\text { 6) Validated method for ascertaining clinical } \\
\text { outcomes? Yes } \\
\text { 7) Outcome assessment blind to exposure? Yes } \\
\text { 8) Adequate follow-up period? Yes; cross-sectional } \\
\text { 9) Completeness of follow-up? Yes } \\
\text { 10) Analysis controls for confounding? Partial; a small } \\
\text { list of potential confounders was included in the } \\
\text { logistic regression model } \\
\text { 11) Analytic methods appropriate? Yes } \\
\text { Funding: Health Care Financing Administration, } \\
\text { Department of } \\
\text { Health and Human Services }\end{array}$ \\
\hline $\begin{array}{l}\text { Quilliam et al. } \\
\text { (2001) [12] }\end{array}$ & $\begin{array}{l}\text { To explore } \\
\text { characteristics of } \\
\text { nursing home } \\
\text { residents who are } \\
\text { stroke survivors and } \\
\text { factors associated } \\
\text { with secondary } \\
\text { prevention of stroke } \\
\text { in nursing homes }\end{array}$ & $\begin{array}{l}\text { Design: } \\
\text { Retrospective } \\
\text { cross-sectional } \\
\text { study } \\
\text { Data source: MDS }\end{array}$ & $\begin{array}{l}\text { Population: 53,829 (20.4\%) } \\
\text { residents aged > } 65 \text { years } \\
\text { with a diagnosis of stroke } \\
\text { (stroke type unknown) } \\
\text { Setting: all nursing home } \\
\text { residents in } 5 \text { states (US) } \\
\text { Time period: 1992-1995 } \\
\end{array}$ & $\begin{array}{l}67 \% \text { of stroke survivors and }>50 \% \text { of those } \\
\text { hospitalized with stroke over the previous } 6 \text { months } \\
\text { were not receiving drug therapy for stroke prevention. } \\
\text { Among those treated, most received aspirin alone } \\
\text { (16\%) or warfarin alone (10\%). Independent predictors } \\
\text { of drug treatment included co-morbid conditions (e.g. } \\
\text { hypertension, } \mathrm{AF} \text {, depression, Alzheimer's disease, } \\
\text { dementia, history of } \mathrm{Gl} \text { bleeding, and peptic ulcer } \\
\text { disease). Those aged } \geq 85 \text { years were less likely to be } \\
\text { treated than those aged } 65-74 \text { years (OR }=0.86 ; 95 \% \\
\mathrm{Cl}=0.82-0.91 \text { ) black residents were less likely to be } \\
\text { treated than whites (OR }=0.80 ; 95 \% \mathrm{Cl}=0.75-0.85) \text {; } \\
\text { and those with severe cognitive }(\mathrm{OR}=0.63 ; 95 \% \mathrm{Cl}= \\
0.60-0.67) \text { or physical impairment }(\mathrm{OR}=0.69 ; 95 \% \mathrm{Cl} \\
=0.64-0.75) \text { were also less likely to receive drug } \\
\text { treatment }\end{array}$ & $\begin{array}{l}\text { Quality assessment for observational studies: } \\
\text { 1) Unbiased selection of the cohort? Yes } \\
\text { 2) Selection minimizes baseline differences in } \\
\text { prognostic factors? Yes } \\
\text { 3) Sample size calculated/5\% difference? Yes } \\
\text { 4) Adequate description of the cohort? Yes } \\
\text { 5) Validated method for ascertaining exposure? Partial; } \\
\text { only a limited set of bleeding risk factors were } \\
\text { considered in the logistic regression model } \\
\text { 6) Validated method for ascertaining clinical } \\
\text { outcomes? Yes } \\
\text { 7) Outcome assessment blind to exposure? Yes } \\
\text { 8) Adequate follow-up period? Yes; cross-sectional } \\
\text { 9) Completeness of follow-up? Yes } \\
\text { 10) Analysis controls for confounding? Yes } \\
\text { 11) Analytic methods appropriate? Yes } \\
\text { Funding: National Institute on Aging, AHRQ }\end{array}$ \\
\hline
\end{tabular}


Table 1 Warfarin indications, rate of use and prescribing patterns (Continued)

\begin{tabular}{|c|c|c|c|c|c|}
\hline $\begin{array}{l}\text { Sloane et al. } \\
\text { (2004) [13] }\end{array}$ & $\begin{array}{l}\text { To determine the } \\
\text { prevalence and } \\
\text { predictors of non- } \\
\text { prescribing of } \\
\text { selected medications } \\
\text { for } 4 \text { common } \\
\text { geriatric conditions } \\
\text { (including aspirin or } \\
\text { anticoagulants for } \\
\text { persons with a history } \\
\text { of stroke) whose } \\
\text { value in decreasing } \\
\text { morbidity has been } \\
\text { established in clinical } \\
\text { trials }\end{array}$ & $\begin{array}{l}\text { Design: Cross- } \\
\text { sectional study } \\
\text { Data source: } \\
\text { patient } \\
\text { characteristics and } \\
\text { diagnoses were } \\
\text { based on medical } \\
\text { record reviews } \\
\text { and in-person } \\
\text { patient } \\
\text { assessments; data } \\
\text { on facility } \\
\text { characteristics } \\
\text { were obtained by } \\
\text { interviewing } \\
\text { facility } \\
\text { administrators }\end{array}$ & $\begin{array}{l}\text { Population: } 2014 \text { residents } \\
\text { aged } \geq 65 \text { years } \\
\text { Setting: a stratified } \\
\text { random sample of } 193 \\
\text { residential care/assisted } \\
\text { living facilities in Florida, } \\
\text { Maryland, New Jersey, } \\
\text { and North Carolina (US) } \\
\text { Time period: Oct } 1997 \text { - } \\
\text { Nov } 1998\end{array}$ & $\begin{array}{l}\text { Of } 435 \text { patients with prior stroke (stroke type not } \\
\text { specified) } 14.4 \% \text { had a contraindication for aspirin use } \\
\text { and } 0 \% \text { had a contraindication for warfarin use. } 37.5 \% \\
\text { were not receiving an anticoagulant or antiplatelet } \\
\text { agent. Neither bivariate nor multivariate analysis } \\
\text { showed an association between non-prescribing and } \\
\text { resident characteristics. Some facility characteristics } \\
\text { were associated with non-prescribing in bivariate } \\
\text { analysis (traditional vs small facility [OR }=0.55 ; P< \\
0.05] \text {, new model vs small facility [OR }=0.47 ; P< \\
0.01] \text {, presence of an RN/LPN [OR }=0.58 ; P<0.05] \text { ). } \\
\text { However, in the multivariate analysis no facility } \\
\text { characteristics were significantly associated with Non- } \\
\text { prescribing }\end{array}$ & $\begin{array}{l}\text { Quality assessment for observational studies: } \\
\text { 1) Unbiased selection of the cohort? Yes } \\
\text { 2) Selection minimizes baseline differences in } \\
\text { prognostic factors? } \\
\text { Yes } \\
\text { 3) Sample size calculated/5\% difference? Yes } \\
\text { 4) Adequate description of the cohort? Yes } \\
\text { 5) Validated method for ascertaining exposure? No; } \\
\text { contraindication to warfarin use not evaluated; } \\
\text { contraindication to aspirin use limited to peptic ulcer } \\
\text { disease } \\
\text { 6) Validated method for ascertaining clinical } \\
\text { outcomes? Yes } \\
\text { 7) Outcome assessment blind to exposure? Yes } \\
\text { 8) Adequate follow-up period? Yes; cross-sectional } \\
\text { 9) Completeness of follow-up? Yes } \\
\text { 10) Analysis controls for confounding? Partial; many } \\
\text { covariates in multiple drug therapy study have little } \\
\text { relevance to warfarin or antiplatelet use } \\
\text { 11) Analytic methods appropriate? Yes } \\
\text { Funding: National Institute on } \\
\text { Aging }\end{array}$ \\
\hline \multicolumn{6}{|c|}{ Part B: Medication management interventions } \\
\hline $\begin{array}{l}\text { Crotty et al. } \\
\text { (2004) [20] }\end{array}$ & $\begin{array}{l}\text { To assess whether } \\
\text { pharmacist outreach } \\
\text { visits would improve } \\
\text { the implementation } \\
\text { of evidence-based } \\
\text { clinical practice in the } \\
\text { area of falls reduction } \\
\text { and stroke prevention } \\
\text { in a residential care } \\
\text { setting }\end{array}$ & $\begin{array}{l}\text { Design: } \\
\text { randomized } \\
\text { control trial } \\
\text { Data source: pre- } \\
\text { and post- } \\
\text { intervention case } \\
\text { note audits }\end{array}$ & $\begin{array}{l}\text { Population: } 452 \text { residential } \\
\text { care staff was surveyed; } \\
121 \text { physicians were } \\
\text { involved, with } 61 \\
\text { receiving outreach visits. } \\
\text { Pre- and post- } \\
\text { intervention data were } \\
\text { available for } 715 \text { LTC } \\
\text { residents } \\
\text { Setting: } 10 \text { nursing homes } \\
\text { and } 10 \text { hostels (low-level } \\
\text { facilities) in South } \\
\text { Australia } \\
\text { Time period: } 7 \text {-month } \\
\text { follow-up period (dates } \\
\text { not specified) }\end{array}$ & $\begin{array}{l}\text { No statistically significant difference between groups } \\
\text { for numbers of patients at risk of stroke on aspirin at } \\
\text { follow-up. Percent of residents with AF recorded on } \\
\text { warfarin was similar between groups: } 22.6 \% \text { (pre) and } \\
17.1 \% \text { (post) in the control group, and } 8.6 \% \text { (pre) and } \\
16.7 \% \text { (post) in the intervention group (RR }=0.92 \text {; } \\
95 \% \mathrm{Cl}=0.23-3.95 \text { ) }\end{array}$ & $\begin{array}{l}\text { Quality assessment for observational studies: } \\
\text { 1) Baseline comparability? Yes } \\
\text { 2) Valid AD/cognitive outcomes assessment? Yes } \\
\text { 3) Subjects/providers blind? Cannot be determined } \\
\text { 4) Outcome assessors blind? Yes } \\
\text { 5) Incomplete data adequately addressed? Yes } \\
\text { 6) Differential dropout rate }<10 \% \text { ? Yes } \\
\text { 7) Overall dropout rate < } 30 \% \text { ? Yes; was } 22.5 \% \text { but as } \\
\text { high as } 37 \% \text { in some cluster facilities } \\
\text { 8) Conflict of interest reported and insignificant? Yes } \\
\text { 9) Randomization adequate? Yes } \\
\text { 10) Allocation concealment adequate? Yes } \\
\text { Funding: National Health \& Medical Research Council } \\
\text { Evidence Based Clinical Practice Research Program }\end{array}$ \\
\hline
\end{tabular}


Table 1 Warfarin indications, rate of use and prescribing patterns (Continued)

\begin{tabular}{|c|c|c|c|c|c|}
\hline $\begin{array}{l}\text { Horning et al. } \\
\text { (2007) [21] }\end{array}$ & $\begin{array}{l}\text { To evaluate clinical } \\
\text { practice guideline } \\
\text { adherence (including } \\
\text { antiplatelet and } \\
\text { anticoagulation } \\
\text { therapy for secondary } \\
\text { stroke in prevention) } \\
\text { in patients LTC } \\
\text { facilities who received } \\
\text { pharmacist-directed } \\
\text { DSM compared with } \\
\text { patients in other LTC } \\
\text { facilities who received } \\
\text { traditional DRR }\end{array}$ & $\begin{array}{l}\text { Design: } \\
\text { retrospective } \\
\text { cohort study } \\
\text { Data source: chart } \\
\text { review }\end{array}$ & $\begin{array}{l}\text { Population: for the } \\
\text { secondary stroke } \\
\text { prevention subgroup, } 18 \\
\text { stroke patients who } \\
\text { received DSM services } \\
\text { and } 86 \text { stroke patients } \\
\text { who received DRR } \\
\text { services } \\
\text { Setting: DSM services } \\
\text { (intervention) in } 2 \text { LTC } \\
\text { facilities and DRR services } \\
\text { (control) in } 4 \text { LTC facilities } \\
\text { (US) } \\
\text { Time period: Nov } 2005\end{array}$ & $\begin{array}{l}\text { For patients with prior stroke, more DSM vs DDR } \\
\text { patients received aspirin, clopidogrel or warfarin or } \\
\text { were recognized with a contraindication (unadjusted, } \\
88.9 \% \text { vs } 69.8 \% \text {; } P=0.096 \text {; adjusted OR }=5.380 ; 95 \% \\
C l=0.975-29.684 \text { ) }\end{array}$ & $\begin{array}{l}\text { Quality assessment for observational studies: } \\
\text { 1) Unbiased selection of the cohort? No; control } \\
\text { group was determined retrospectively } \\
\text { 2) Selection minimizes baseline differences in } \\
\text { prognostic factors? Partial; control group was } \\
\text { determined by authors to be representative mix of } \\
\text { local usual pharmacist consultant services } \\
\text { 3) Sample size calculated/5\% difference? No; } \\
\text { intervention group may have lacked power due to } \\
\text { low n = } 107 \text { residents } \\
\text { 4) Adequate description of the cohort? Yes } \\
\text { 5) Validated method for ascertaining exposure? Partial; } \\
\text { description of DSM intervention for each of seven } \\
\text { diseases evaluated was limited } \\
\text { 6) Validated method for ascertaining clinical } \\
\text { outcomes? Partial; description of guideline adherence } \\
\text { scoring limited; only cite consensual guidelines } \\
\text { 7) Outcome assessment blind to exposure? No } \\
\text { 8) Adequate follow-up period? Yes } \\
\text { 9) Completeness of follow-up? Yes } \\
\text { 10) Analysis controls for confounding? No; did not } \\
\text { adjust for institutional characteristics in logistic } \\
\text { regression models } \\
\text { 11) Analytic methods appropriate? No; limited } \\
\text { covariate set unchanged among seven disease logistic } \\
\text { regression models; stroke and bleeding risk not } \\
\text { adequately modeled; no multiplicity adjustment } \\
\text { Funding: No outside funding. }\end{array}$ \\
\hline $\begin{array}{l}\text { Papaioannou } \\
\text { et al. (2010) } \\
\text { [24] }\end{array}$ & $\begin{array}{l}\text { To evaluate the } \\
\text { MEDelNR system (an } \\
\text { electronic decision } \\
\text { support system based } \\
\text { on a validated } \\
\text { algorithm for warfarin } \\
\text { dosing) by examining } \\
\text { the impact on INR } \\
\text { control, testing } \\
\text { frequency, and } \\
\text { experiences of staff in } \\
\text { using the system }\end{array}$ & $\begin{array}{l}\text { Design: } \\
\text { retrospective/ } \\
\text { prospective } \\
\text { cohort study (pre- } \\
\text { post } \\
\text { implementation } \\
\text { design) } \\
\text { Data source: pre- } \\
\text { implementation: } \\
\text { retrospective chart } \\
\text { audit; post- } \\
\text { implementation: } \\
\text { central computer } \\
\text { database }\end{array}$ & $\begin{array}{l}\text { Population: } 128 \text { residents } \\
\text { (without prosthetic valve) } \\
\text { who were taking warfarin } \\
\text { Setting: } 6 \text { LTC homes in } \\
\text { Ontario (Canada) } \\
\text { Time period: } 6 \text { months, } 3 \\
\text { months prior to MEDeINR } \\
\text { implementation and } 3 \\
\text { months post- } \\
\text { implementation (dates } \\
\text { not specified) }\end{array}$ & $\begin{array}{l}128(10 \%) \text { of all residents (excluding those with a } \\
\text { prosthetic valve) were taking warfarin in } 6 \text { LTC homes. } \\
\text { The primary indications for taking warfarin were: AF } \\
(74 \%) \text {, DVT (20\%), and PE (6\%) }\end{array}$ & $\begin{array}{l}\text { Quality assessment for observational studies: } \\
\text { 1) Unbiased selection of the cohort? No; potential } \\
\text { survivor bias since residents who discontinued } \\
\text { warfarin prior to intervention due to poor INR control } \\
\text { would not have been eligible for study } \\
\text { 2) Selection minimizes baseline differences in } \\
\text { prognostic factors? Partial; pre- and post-intervention } \\
\text { without control does not adjust for biases such as } \\
\text { history and maturation } \\
\text { 3) Sample size calculated/5\% difference? Yes } \\
\text { 4) Adequate description of the cohort? Yes } \\
\text { 5) Validated method for ascertaining exposure? Yes } \\
\text { 6) Validated method for ascertaining clinical } \\
\text { outcomes? Yes } \\
\text { 7) Outcome assessment blind to exposure? No } \\
\text { 8) Adequate follow-up period? Partial; some residents } \\
\text { had < } 3 \text { months of follow-up } \\
\text { 9) Completeness of follow-up? No; differential follow- } \\
\text { up in pre- and post- periods not evaluated } \\
\text { 10) Analysis controls for confounding? Partial; no } \\
\text { covariates modeled since subjects served as own } \\
\text { controls; assumes no time-varying relevant covariates } \\
\text { 11) Analytic methods appropriate? Partial; sensitivity } \\
\text { analysis to test survivor bias not performed } \\
\text { Funding: Canadian Institute of Health Research }\end{array}$ \\
\hline
\end{tabular}


from $17 \%$ [9] to $57 \%$ [10], while the rate of either warfarin or antiplatelet use ranged from $62 \%$ [13] to $80 \%$ [10].

\section{Rate of warfarin use among AF patients}

Of the eight studies above, five $(n=10,308)$ [7-11] reported rates of warfarin use among LTC residents with AF that ranged from 17\% [9] to 57\%[10]. Abdel-Latif and colleagues [7] found that $46 \%$ of 117 residents with AF in six LTC facilities had been prescribed warfarin; 79\% received either warfarin, aspirin, or clopidogrel. In a study of 265 LTC residents with AF in Canada from 2001-2002, Lau et al.[10] found that warfarin was prescribed for 57\%; among residents who were considered optimal candidates (high risk of stroke and low risk of bleeding according to the criteria used in this study [10]), the warfarin prescribing rate was 60\%. Using 1993 data, Lackner et al. [9], in a study of five LTC facilities, found that only $17 \%$ of patients with non-valvular AF received warfarin; among residents with AF with $\geq 1$ additional risk factor for stroke (besides AF) and no contraindication to warfarin use, only $20 \%$ received warfarin [9]. Gurwitz et al. [8], using data from 1993 to 1995, found rates of warfarin use of $32 \%$ in 413 residents with AF. Finally, in a study of 21 LTC facilities from 1997 to 1998, McCormick et al. [11] reported that $42 \%$ of residents with AF received warfarin, and only $53 \%$ of ideal AF candidates for warfarin therapy (those having no bleeding risk factors) received it.

\section{Rate of warfarin use among stroke patients}

Three studies measured the use of warfarin in LTC facilities among stroke survivors (Table 1 Part A) $[12,13,19]$. Lapane et al. [19] evaluated, among stroke survivors, whether introduction of a prospective payment system (PPS) that required nursing homes to bear the cost for warfarin monitoring had shifted utilization from warfarin to antiplatelet agents. Comparing data from 1997 and 2000, Lapane et al. [19] found that the use of warfarin for the secondary prevention of ischemic stroke did not change significantly following the introduction of the PPS, from $22 \%$ in 1997 to $23 \%$ in 2000 , while antiplatelet use did increase from $41 \%$ to $48 \%$ over the same period (likely due to the introduction of clopidogrel). Sloane et al. [13] examined 1997-1998 data from residential care/ assisted living facilities in the United States and found that $38 \%$ of the 435 residents with a history of stroke (type not specified) received neither warfarin nor an antiplatelet agent. Quilliam et al. [12] analyzed records of 53,829 survivors of stroke (either ischemic or hemorrhagic) in all nursing homes in five states from 1992 to 1995 (SAGE database) and found that $67 \%$ were not receiving warfarin or any antiplatelet medication for stroke prevention; among residents recently hospitalized for ischemic stroke, $52 \%$ did not receive either of these agents.

\section{Association of Resident and/or Facility Characteristics with Warfarin Prescribing}

Eight studies $[7,8,10-13,17,18]$ (a subset of the studies shown in Table $1 ; \mathrm{n}=100,879$ ), explored the relationship between warfarin or combined warfarin/antiplatelet usage and resident or facility characteristics. All studies used multivariate models to adjust for potential confounders. The direction (negative, positive, none noted [i.e. not significant]) and strength (reported odds ratio [OR]) of reported associations within these multivariate models are summarized in Table 2.

\section{Previous stroke or transient ischemic attack}

Among residents with AF in LTC facilities, both AbdelLatif et al. [7] $(\mathrm{OR}=4.93,95 \%$ confidence interval $[\mathrm{CI}]=$ 2.11-11.49 [correction provided by these authors]) and Gurwitz et al. [8] (OR $=1.87,95 \% \mathrm{CI}=1.20-2.91)$, found a positive association between having a history of stroke and receiving warfarin. However, Lau et al. [10] found no significant association between "previous stroke or transient ischemic attack" and warfarin in residents with AF.

\section{Atrial fibrillation}

Both Quilliam et al. [12] $(\mathrm{OR}=2.04,95 \% \mathrm{CI}=1.95-2.14)$ and Hughes et al. [18] $(\mathrm{OR}=1.76,95 \% \mathrm{CI}=1.50-2.06)$ found that stroke survivors with AF were twice as likely to receive or be initiated on warfarin or antiplatelet therapy, compared with stroke survivors without AF.

\section{Other stroke risk factors}

Although both Lau et al. [10] and McCormick et al. [11] evaluated the association between degree of overall stroke risk and use of warfarin in LTC residents with AF, neither study found a significant association. In one study, [12] coronary artery disease was significantly associated (OR = $1.06,95 \% \mathrm{CI}=1.02-1.11$ ) with use of warfarin or antiplatelets among stroke survivors, but in another study [10] it was not associated with use of warfarin in residents with AF. While two studies found no significant association between hypertension and use of warfarin in residents with AF $[7,10]$, two other studies found that in stroke survivors hypertension was positively associated with initiation [18] $(\mathrm{OR}=1.23,95 \% \mathrm{CI}=1.09-1.39)$ and use [12] $(\mathrm{OR}=1.27,95 \% \mathrm{CI}=1.22-1.32)$ of warfarin or antiplatelets.

\section{Depression}

Both Hughes et al. [18] $(\mathrm{OR}=1.22,95 \% \mathrm{CI}=1.02-1.46)$ and Quilliam et al. [12] ( $\mathrm{OR}=1.11,95 \% \mathrm{CI}=1.05-1.18)$ found that stroke survivors with depression were more likely to initiate or receive warfarin or antiplatelet therapy. Age

Both Gurwitz et al. [8], studying residents with AF (OR = $0.46,95 \% \mathrm{CI}=0.22-0.94)$, and Quilliam et al. [12], studying stroke survivors $(\mathrm{OR}=0.86,95 \% \mathrm{CI}=0.82-0.91)$, found that residents $\geq 85$ years were less likely to be prescribed either warfarin [8] or warfarin or antiplatelets [12]. 
Table 2 Association of factors with warfarin prescribing

\begin{tabular}{|c|c|c|c|c|c|c|}
\hline Category & Factor & $\begin{array}{l}\text { Direction of association } \\
\text { (at } 95 \% \text { confidence) } \\
0=\text { none }+=\text { positive }-= \\
\text { negative }\end{array}$ & $\begin{array}{l}\text { Association (multivariate } \\
\text { adjusted) }(\mathrm{OR}, 95 \% \mathrm{Cl})\end{array}$ & Endpoint & Study Condition & Study \\
\hline \multirow[t]{2}{*}{ Admission } & Admitted from hospital & + & $\begin{array}{l}\mathrm{OR}=1.16 \\
(1.02-1.31)\end{array}$ & discontinue warfarin or antiplatelets & Previous stroke & $\begin{array}{l}\text { Hughes et al. } \\
\text { (2004) [18] }\end{array}$ \\
\hline & & 0 & $\begin{array}{l}\mathrm{OR}=1.12 \\
(0.97-1.29)\end{array}$ & initiate warfarin or antiplatelets & Previous stroke & $\begin{array}{l}\text { Hughes et al. } \\
\text { (2004) [18] }\end{array}$ \\
\hline \multirow[t]{12}{*}{ Age } & $65-74$ & 0 & $\begin{array}{l}\mathrm{OR}=0.98 \\
(0.61-1.57)\end{array}$ & use of warfarin & AF & $\begin{array}{l}\text { Lau et al. } \\
(2004)[10]\end{array}$ \\
\hline & $75-84$ & 0 & $\begin{array}{l}\mathrm{OR}=0.98 \\
(0.61-1.58)\end{array}$ & use of warfarin & AF & $\begin{array}{l}\text { Lau et al. } \\
\text { (2004) [10] }\end{array}$ \\
\hline & & 0 & $\begin{array}{l}\mathrm{OR}=1.13 \\
(0.98-1.31)\end{array}$ & discontinue warfarin or antiplatelets & Previous stroke & $\begin{array}{l}\text { Hughes et al. } \\
\text { (2004) [18] }\end{array}$ \\
\hline & & 0 & $\begin{array}{l}\mathrm{OR}=0.99 \\
(0.94-1.04)\end{array}$ & use of warfarin or antiplatelets & Previous stroke & $\begin{array}{l}\text { Quilliam et al. } \\
\text { (2001) [12] }\end{array}$ \\
\hline & & 0 & not reported & use of warfarin & AF & $\begin{array}{l}\text { Gurwitz et al. } \\
\text { (1997) [8] }\end{array}$ \\
\hline & & 0 & $\begin{array}{l}\mathrm{OR}=1.01 \\
(0.86-1.19)\end{array}$ & initiate warfarin or antiplatelets & Previous stroke & $\begin{array}{l}\text { Hughes et al. } \\
\text { (2004) [18] }\end{array}$ \\
\hline & $\geq 85$ & 0 & $\begin{array}{l}\mathrm{OR}=1.13 \\
(0.70-1.82)\end{array}$ & use of warfarin & AF & $\begin{array}{l}\text { Lau et al. } \\
\text { (2004) [10] }\end{array}$ \\
\hline & & 0 & $\begin{array}{l}\mathrm{OR}=1.07 \\
\text { (Cl not reported) }\end{array}$ & use of warfarin or antiplatelets & Previous stroke & $\begin{array}{l}\text { Sloane et al. } \\
\text { (2004) [13] }\end{array}$ \\
\hline & & + & $\begin{array}{l}\mathrm{OR}=1.23 \\
(1.05-1.43)\end{array}$ & discontinue warfarin or antiplatelets & Previous stroke & $\begin{array}{l}\text { Hughes et al. } \\
\text { (2004) [18] }\end{array}$ \\
\hline & & - & $\begin{array}{l}\mathrm{OR}=0.46 \\
(0.22-0.94)\end{array}$ & use of warfarin & AF & $\begin{array}{l}\text { Gurwitz et al. } \\
\text { (1997) [8] }\end{array}$ \\
\hline & & - & $\begin{array}{l}\mathrm{OR}=0.86 \\
(0.82-0.91)\end{array}$ & use of warfarin or antiplatelets & Previous stroke & $\begin{array}{l}\text { Quilliam et al. } \\
\text { (2001) [12] }\end{array}$ \\
\hline & & 0 & $\begin{array}{l}\mathrm{OR}=0.86 \\
(0.72-1.04)\end{array}$ & initiate warfarin or antiplatelets & Previous stroke & $\begin{array}{l}\text { Hughes et al. } \\
\text { (2004) [18] }\end{array}$ \\
\hline \multirow[t]{3}{*}{ Bleeding risk } & 1 risk factor & 0 & $\begin{array}{l}\mathrm{OR}=0.75 \\
(0.41-1.36)\end{array}$ & use of warfarin & AF & $\begin{array}{l}\text { McCormick et } \\
\text { al. (2001) [11] }\end{array}$ \\
\hline & $\geq 2$ risk factors & - & $\begin{array}{l}\mathrm{OR}=0.51 \\
(0.29-0.94)\end{array}$ & use of warfarin & AF & $\begin{array}{l}\text { McCormick et } \\
\text { al. (2001) [11] }\end{array}$ \\
\hline & High risk & 0 & $\begin{array}{l}\mathrm{OR}=0.82 \\
(0.52-1.30)\end{array}$ & use of warfarin & AF & $\begin{array}{l}\text { Lau et al. } \\
\text { (2004) [10] }\end{array}$ \\
\hline \multirow[t]{2}{*}{$\begin{array}{l}\text { Cognitive } \\
\text { impairment }\end{array}$} & Moderate & - & $\begin{array}{l}\mathrm{OR}=0.93 \\
(0.88-0.97)\end{array}$ & use of warfarin or antiplatelets & Previous stroke & $\begin{array}{l}\text { Quilliam et al. } \\
\text { (2001) [12] }\end{array}$ \\
\hline & & 0 & $\begin{array}{l}\mathrm{OR}=0.93 \\
(0.81-1.08)\end{array}$ & initiate warfarin or antiplatelets & Previous stroke & $\begin{array}{l}\text { Hughes et al. } \\
\text { (2004) [18] }\end{array}$ \\
\hline
\end{tabular}


Table 2 Association of factors with warfarin prescribing (Continued)

\begin{tabular}{|c|c|c|c|c|c|c|}
\hline & & 0 & $\begin{array}{l}\mathrm{OR}=0.98 \\
(0.86-1.12)\end{array}$ & discontinue warfarin or antiplatelets & Previous stroke & $\begin{array}{l}\text { Hughes et al. } \\
\text { (2004) [18] }\end{array}$ \\
\hline & \multirow[t]{4}{*}{ Severe } & 0 & $\begin{array}{l}\mathrm{OR}=1.19 \\
(0.99-1.44)\end{array}$ & discontinue warfarin or antiplatelets & Previous stroke & $\begin{array}{l}\text { Hughes et al. } \\
\text { (2004) [18] }\end{array}$ \\
\hline & & - & $\begin{array}{l}\mathrm{OR}=0.64 \\
(0.52-0.80)\end{array}$ & initiate warfarin or antiplatelets & Previous stroke & $\begin{array}{l}\text { Hughes et al. } \\
\text { (2004) [18] }\end{array}$ \\
\hline & & - & $\begin{array}{l}\mathrm{OR}=0.63 \\
(0.60-0.67)\end{array}$ & use of warfarin or antiplatelets & Previous stroke & $\begin{array}{l}\text { Quilliam et al. } \\
\text { (2001) [12] }\end{array}$ \\
\hline & & 0 & $\begin{array}{l}\mathrm{OR}=1.02 \\
(\mathrm{Cl} \text { not reported) }\end{array}$ & use of warfarin or antiplatelets & Previous stroke & $\begin{array}{l}\text { Sloane et al. } \\
\text { (2004) [13] }\end{array}$ \\
\hline \multirow[t]{16}{*}{ Conditions } & Active malignancy & 0 & $\begin{array}{l}\mathrm{OR}=0.93 \\
(0.57-1.51)\end{array}$ & use of warfarin & $\mathrm{AF}$ & $\begin{array}{l}\text { Lau et al. } \\
(2004)[10]\end{array}$ \\
\hline & Alzheimer's disease & - & $\begin{array}{l}\mathrm{OR}=0.77 \\
(0.70-0.85)\end{array}$ & use of warfarin or antiplatelets & Previous stroke & $\begin{array}{l}\text { Quilliam et al. } \\
\text { (2001) [12] }\end{array}$ \\
\hline & Anemia & 0 & $\begin{array}{l}\mathrm{OR}=0.87 \\
(0.55-1.39)\end{array}$ & use of warfarin & $A F$ & $\begin{array}{l}\text { Lau et al. } \\
\text { (2004) [10] }\end{array}$ \\
\hline & Aneurysms & 0 & $\begin{array}{l}\mathrm{OR}=0.88 \\
(0.55-1.40)\end{array}$ & use of warfarin & $\mathrm{AF}$ & $\begin{array}{l}\text { Lau et al. } \\
\text { (2004) [10] }\end{array}$ \\
\hline & Atrial fibrillation & - & $\begin{array}{l}\mathrm{OR}=0.73 \\
(0.64-0.83)\end{array}$ & discontinue warfarin or antiplatelets & Previous stroke & $\begin{array}{l}\text { Hughes et al. } \\
\text { (2004) [18] }\end{array}$ \\
\hline & & + & $\begin{array}{l}\mathrm{OR}=1.76 \\
(1.50-2.06)\end{array}$ & initiate warfarin or antiplatelets & Previous stroke & $\begin{array}{l}\text { Hughes et al. } \\
\text { (2004) [18] }\end{array}$ \\
\hline & & + & $\begin{array}{l}\mathrm{OR}=2.04 \\
(1.95-2.14)\end{array}$ & use of warfarin or antiplatelets & Previous stroke & $\begin{array}{l}\text { Quilliam et al. } \\
\text { (2001) [12] }\end{array}$ \\
\hline & Congestive heart failure & 0 & $\begin{array}{l}\mathrm{OR}=1.13 \\
(0.98-1.30)\end{array}$ & discontinue warfarin or antiplatelets & Previous stroke & $\begin{array}{l}\text { Hughes et al. } \\
\text { (2004) [18] }\end{array}$ \\
\hline & & 0 & $\begin{array}{l}\mathrm{OR}=1.04 \\
(0.65-1.65)\end{array}$ & use of warfarin & AF & $\begin{array}{l}\text { Lau et al. } \\
\text { (2004) [10] }\end{array}$ \\
\hline & & 0 & not reported & use of warfarin & AF & $\begin{array}{l}\text { Abdel-Latif et } \\
\text { al. (2005) [7] }\end{array}$ \\
\hline & & 0 & $\begin{array}{l}\mathrm{OR}=1.02 \\
(0.87-1.20)\end{array}$ & initiate warfarin or antiplatelets & Previous stroke & $\begin{array}{l}\text { Hughes et al. } \\
\text { (2004) [18] }\end{array}$ \\
\hline & Coronary artery disease & + & $\begin{array}{l}\mathrm{OR}=1.06 \\
(1.02-1.11)\end{array}$ & use of warfarin or antiplatelets & Previous stroke & $\begin{array}{l}\text { Quilliam et al. } \\
\text { (2001) [12] }\end{array}$ \\
\hline & & 0 & $\begin{array}{l}\mathrm{OR}=0.99 \\
(0.62-1.58)\end{array}$ & use of warfarin & $\mathrm{AF}$ & $\begin{array}{l}\text { Lau et al. } \\
\text { (2004) [10] }\end{array}$ \\
\hline & Dementia & - & $\begin{array}{l}\mathrm{OR}=0.84 \\
(0.80-0.88)\end{array}$ & use of warfarin or antiplatelets & Previous stroke & $\begin{array}{l}\text { Quilliam et al. } \\
\text { (2001) [12] }\end{array}$ \\
\hline & & - & $\begin{array}{l}\mathrm{OR}=0.59 \\
(0.38-0.90)\end{array}$ & use of warfarin & $\mathrm{AF}$ & $\begin{array}{l}\text { Gurwitz et al. } \\
\text { (1997) [8] }\end{array}$ \\
\hline & Depression & + & $\begin{array}{l}\mathrm{OR}=1.22 \\
(1.02-1.46)\end{array}$ & initiate warfarin or antiplatelets & Previous stroke & $\begin{array}{l}\text { Hughes et al. } \\
\text { (2004) [18] }\end{array}$ \\
\hline
\end{tabular}


Table 2 Association of factors with warfarin prescribing (Continued)

\begin{tabular}{|c|c|c|c|c|c|}
\hline & + & $\begin{array}{l}\mathrm{OR}=1.11 \\
(1.05-1.18)\end{array}$ & use of warfarin or antiplatelets & Previous stroke & $\begin{array}{l}\text { Quilliam et al. } \\
\text { (2001) [12] }\end{array}$ \\
\hline & 0 & $\begin{array}{l}\mathrm{OR}=1.08 \\
(0.93-1.24)\end{array}$ & discontinue warfarin or antiplatelets & Previous stroke & $\begin{array}{l}\text { Hughes et al. } \\
\text { (2004) [18] }\end{array}$ \\
\hline \multirow[t]{2}{*}{ Diabetes mellitus } & 0 & not reported & use of warfarin & AF & $\begin{array}{l}\text { Abdel-Latif et } \\
\text { al. (2005) [7] }\end{array}$ \\
\hline & 0 & $\begin{array}{l}\mathrm{OR}=1.17 \\
(0.73-1.86)\end{array}$ & use of warfarin & AF & $\begin{array}{l}\text { Lau et al. } \\
\text { (2004) [10] }\end{array}$ \\
\hline \multirow[t]{5}{*}{ Hypertension } & - & $\begin{array}{l}\mathrm{OR}=0.87 \\
(0.78-0.97)\end{array}$ & discontinue warfarin or antiplatelets & Previous stroke & $\begin{array}{l}\text { Hughes et al. } \\
\text { (2004) [18] }\end{array}$ \\
\hline & + & $\begin{array}{l}\mathrm{OR}=1.23 \\
(1.09-1.39)\end{array}$ & initiate warfarin or antiplatelets & Previous stroke & $\begin{array}{l}\text { Hughes et al. } \\
\text { (2004) [18] }\end{array}$ \\
\hline & 0 & $\begin{array}{l}\mathrm{OR}=1.10 \\
(0.69-1.75)\end{array}$ & use of warfarin & AF & $\begin{array}{l}\text { Lau et al. } \\
\text { (2004) [10] }\end{array}$ \\
\hline & 0 & not reported & use of warfarin & AF & $\begin{array}{l}\text { Abdel-Latif et } \\
\text { al. (2005) [7] }\end{array}$ \\
\hline & + & $\begin{array}{l}\mathrm{OR}=1.27 \\
(1.22-1.32)\end{array}$ & use of warfarin or antiplatelets & Previous stroke & $\begin{array}{l}\text { Quilliam et al. } \\
\text { (2001) [12] }\end{array}$ \\
\hline \multirow[t]{2}{*}{ Left ventricular dysfunction } & 0 & $\begin{array}{l}\mathrm{OR}=0.83 \\
(0.63-1.09)\end{array}$ & initiate warfarin or antiplatelets & Previous stroke & $\begin{array}{l}\text { Hughes et al. } \\
\text { (2004) [18] }\end{array}$ \\
\hline & 0 & $\begin{array}{l}\mathrm{OR}=1.07 \\
(0.88-1.30)\end{array}$ & discontinue warfarin or antiplatelets & Previous stroke & $\begin{array}{l}\text { Hughes et al. } \\
\text { (2004) [18] }\end{array}$ \\
\hline Liver disease & 0 & $\begin{array}{l}\mathrm{OR}=1.53 \\
(0.95-2.49)\end{array}$ & use of warfarin & AF & $\begin{array}{l}\text { Lau et al. } \\
(2004)[10]\end{array}$ \\
\hline Major comorbidity burden & 0 & not reported & use of warfarin & AF & $\begin{array}{l}\text { Gurwitz et al. } \\
\text { (1997) [8] }\end{array}$ \\
\hline $\begin{array}{l}\text { Moderate comorbidity } \\
\text { burden }\end{array}$ & 0 & not reported & use of warfarin & AF & $\begin{array}{l}\text { Gurwitz et al. } \\
\text { (1997) [8] }\end{array}$ \\
\hline $\begin{array}{l}\text { Multiple conditions ( } 4 \text { or } \\
\text { more) }\end{array}$ & 0 & $\begin{array}{l}\mathrm{OR}=0.84 \\
(\mathrm{Cl} \text { not reported })\end{array}$ & use of warfarin or antiplatelets & Previous stroke & $\begin{array}{l}\text { Sloane et al. } \\
\text { (2004) [13] }\end{array}$ \\
\hline \multirow[t]{2}{*}{ Peptic ulcer disease } & 0 & $\begin{array}{l}\mathrm{OR}=0.90 \\
(0.57-1.43)\end{array}$ & use of warfarin & AF & $\begin{array}{l}\text { Lau et al. } \\
(2004)[10]\end{array}$ \\
\hline & - & $\begin{array}{l}\mathrm{OR}=0.64 \\
(0.58-0.71)\end{array}$ & use of warfarin or antiplatelets & Previous stroke & $\begin{array}{l}\text { Quilliam et al. } \\
\text { (2001) [12] }\end{array}$ \\
\hline Peripheral vascular disease & + & $\begin{array}{l}\mathrm{OR}=1.13 \\
(1.05-1.20)\end{array}$ & use of warfarin or antiplatelets & Previous stroke & $\begin{array}{l}\text { Quilliam et al. } \\
\text { (2001) [12] }\end{array}$ \\
\hline Previous bleeding & 0 & not reported & use of warfarin & AF & $\begin{array}{l}\text { Gurwitz et al. } \\
\text { (1997) [8] }\end{array}$ \\
\hline Previous falls & 0 & not reported & use of warfarin & AF & $\begin{array}{l}\text { Gurwitz et al. } \\
\text { (1997) [8] }\end{array}$ \\
\hline Previous GI bleeding & - & $\begin{array}{l}\mathrm{OR}=0.57 \\
(0.52-0.62)\end{array}$ & use of warfarin or antiplatelets & Previous stroke & $\begin{array}{l}\text { Quilliam et al. } \\
\text { (2001) [12] }\end{array}$ \\
\hline
\end{tabular}


Table 2 Association of factors with warfarin prescribing (Continued)

\begin{tabular}{|c|c|c|c|c|c|c|}
\hline & & - & $\begin{array}{l}\mathrm{OR}=0.18 \\
(0.03-0.91)\end{array}$ & use of warfarin & $\mathrm{AF}$ & $\begin{array}{l}\text { Abdel-Latif et } \\
\text { al. (2005) [7] }\end{array}$ \\
\hline & Previous major bleeding & 0 & $\begin{array}{l}\mathrm{OR}=0.73 \\
(0.46-1.15)\end{array}$ & use of warfarin & AF & $\begin{array}{l}\text { Lau et al. } \\
(2004)[10]\end{array}$ \\
\hline & \multirow[t]{2}{*}{ Previous stroke } & + & $\begin{array}{l}\mathrm{OR}=4.93 \\
(2.11-11.49)\end{array}$ & use of warfarin & AF & $\begin{array}{l}\text { Abdel-Latif et } \\
\text { al. (2005) [7] }\end{array}$ \\
\hline & & + & $\begin{array}{l}\mathrm{OR}=1.87 \\
(1.20-2.91)\end{array}$ & use of warfarin & $\mathrm{AF}$ & $\begin{array}{l}\text { Gurwitz et al. } \\
\text { (1997) [8] }\end{array}$ \\
\hline & Previous stroke or TIA & 0 & $\begin{array}{l}\mathrm{OR}=1.24 \\
(0.78-1.97)\end{array}$ & use of warfarin & AF & $\begin{array}{l}\text { Lau et al. } \\
(2004)[10]\end{array}$ \\
\hline & Previous systemic embolus & 0 & $\begin{array}{l}\mathrm{OR}=1.46 \\
(0.92-2.34)\end{array}$ & use of warfarin & $\mathrm{AF}$ & $\begin{array}{l}\text { Lau et al. } \\
\text { (2004) [10] }\end{array}$ \\
\hline & Recent surgery & - & $\begin{array}{l}\mathrm{OR}=0.59 \\
(0.37-0.94)\end{array}$ & use of warfarin & $\mathrm{AF}$ & $\begin{array}{l}\text { Lau et al. } \\
\text { (2004) [10] }\end{array}$ \\
\hline & Renal insufficiency & 0 & $\begin{array}{l}\mathrm{OR}=0.91 \\
(0.57-1.45)\end{array}$ & use of warfarin & AF & $\begin{array}{l}\text { Lau et al. } \\
\text { (2004) [10] }\end{array}$ \\
\hline & Rheumatic mitral valvular & 0 & $\begin{array}{l}\mathrm{OR}=0.80 \\
(0.50-1.28)\end{array}$ & use of warfarin & AF & $\begin{array}{l}\text { Lau et al. } \\
(2004)[10]\end{array}$ \\
\hline & Seizure disorder & 0 & $\begin{array}{l}\mathrm{OR}=1.05 \\
(0.66-1.67)\end{array}$ & use of warfarin & AF & $\begin{array}{l}\text { Lau et al. } \\
(2004)[10]\end{array}$ \\
\hline & Transient ischemic attack & + & $\begin{array}{l}\mathrm{OR}=1.34 \\
(1.09-1.64)\end{array}$ & initiate warfarin or antiplatelets & Previous stroke & $\begin{array}{l}\text { Hughes et al. } \\
\text { (2004) [18] }\end{array}$ \\
\hline & & 0 & $\begin{array}{l}\mathrm{OR}=0.99 \\
(0.84-1.17)\end{array}$ & discontinue warfarin or antiplatelets & Previous stroke & $\begin{array}{l}\text { Hughes et al. } \\
\text { (2004) [18] }\end{array}$ \\
\hline \multirow[t]{2}{*}{$\begin{array}{l}\text { Drug } \\
\text { Interaction }\end{array}$} & $\begin{array}{l}\text { Uses meds that increase } \\
\text { bleeding risk }\end{array}$ & 0 & not reported & use of warfarin & $\mathrm{AF}$ & $\begin{array}{l}\text { Gurwitz et al. } \\
\text { (1997) [8] }\end{array}$ \\
\hline & & 0 & $\begin{array}{l}\mathrm{OR}=1.26 \\
(0.80-1.98)\end{array}$ & use of warfarin & AF & $\begin{array}{l}\text { Lau et al. } \\
\text { (2004) [10] }\end{array}$ \\
\hline \multirow[t]{3}{*}{$\begin{array}{l}\text { Duration of } \\
\mathrm{AF}\end{array}$} & 12-24 months & 0 & not reported & use of warfarin & AF & $\begin{array}{l}\text { Gurwitz et al. } \\
\text { (1997) [8] }\end{array}$ \\
\hline & $>24$ months & 0 & not reported & use of warfarin & AF & $\begin{array}{l}\text { Gurwitz et al. } \\
\text { (1997) [8] }\end{array}$ \\
\hline & Onset of AF after admission & 0 & not reported & use of warfarin & AF & $\begin{array}{l}\text { Gurwitz et al. } \\
\text { (1997) [8] }\end{array}$ \\
\hline \multirow[t]{4}{*}{ Facility } & Alzheimer's unit & 0 & $\begin{array}{l}\mathrm{OR}=0.78 \\
(0.57-1.05)\end{array}$ & discontinue warfarin or antiplatelets & Previous stroke & $\begin{array}{l}\text { Hughes et al. } \\
\text { (2004) [18] }\end{array}$ \\
\hline & & 0 & $\begin{array}{l}\mathrm{OR}=1.14 \\
(0.80-1.62)\end{array}$ & initiate warfarin or antiplatelets & Previous stroke & $\begin{array}{l}\text { Hughes et al. } \\
\text { (2004) [18] }\end{array}$ \\
\hline & Hospital based & 0 & $\begin{array}{l}\mathrm{OR}=0.96 \\
(0.72-1.29)\end{array}$ & initiate warfarin or antiplatelets & Previous stroke & $\begin{array}{l}\text { Hughes et al. } \\
\text { (2004) [18] }\end{array}$ \\
\hline & & 0 & $\begin{array}{l}\mathrm{OR}=0.96 \\
(0.75-1.23)\end{array}$ & discontinue warfarin or antiplatelets & Previous stroke & $\begin{array}{l}\text { Hughes et al. } \\
\text { (2004) [18] }\end{array}$ \\
\hline
\end{tabular}


Table 2 Association of factors with warfarin prescribing (Continued)

\begin{tabular}{|c|c|c|c|c|c|}
\hline Location rural & 0 & $\begin{array}{l}\mathrm{OR}=0.89 \\
(\mathrm{Cl} \text { not reported })\end{array}$ & use of warfarin or antiplatelets & Previous stroke & $\begin{array}{l}\text { Sloane et al. } \\
\text { (2004) [13] }\end{array}$ \\
\hline \multirow[t]{2}{*}{ Location urban } & + & $\begin{array}{l}\mathrm{OR}=1.38 \\
(1.16-1.65)\end{array}$ & discontinue warfarin or antiplatelets & Previous stroke & $\begin{array}{l}\text { Hughes et al. } \\
\text { (2004) [18] }\end{array}$ \\
\hline & 0 & $\begin{array}{l}\mathrm{OR}=1.06 \\
(0.87-1.3)\end{array}$ & initiate warfarin or antiplatelets & Previous stroke & $\begin{array}{l}\text { Hughes et al. } \\
\text { (2004) [18] }\end{array}$ \\
\hline $\begin{array}{l}\text { Large new model facility (vs } \\
\text { small) }\end{array}$ & 0 & $\begin{array}{l}\mathrm{OR}=0.61 \\
(\mathrm{Cl} \text { not reported) }\end{array}$ & use of warfarin or antiplatelets & Previous stroke & $\begin{array}{l}\text { Sloane et al. } \\
\text { (2004) [13] }\end{array}$ \\
\hline \multirow[t]{2}{*}{$\begin{array}{l}\text { Non-white > 10\% (vs > 0\% } \\
\text { to < } 5 \% \text { ) }\end{array}$} & 0 & $\begin{array}{l}\mathrm{OR}=1.09 \\
(0.91-1.32)\end{array}$ & initiate warfarin or antiplatelets & Previous stroke & $\begin{array}{l}\text { Hughes et al. } \\
\text { (2004) [18] }\end{array}$ \\
\hline & + & $\begin{array}{l}\mathrm{OR}=1.22 \\
(1.03-1.43)\end{array}$ & discontinue warfarin or antiplatelets & Previous stroke & $\begin{array}{l}\text { Hughes et al. } \\
\text { (2004) [18] }\end{array}$ \\
\hline \multirow[t]{2}{*}{$\begin{array}{l}\text { Non-white }>5 \% \text { to }<10 \% \\
\text { (vs }>0 \% \text { to }<5 \% \text { ) }\end{array}$} & 0 & $\begin{array}{l}\mathrm{OR}=1.00 \\
(0.81-1.24)\end{array}$ & initiate warfarin or antiplatelets & Previous stroke & $\begin{array}{l}\text { Hughes et al. } \\
\text { (2004) [18] }\end{array}$ \\
\hline & 0 & $\begin{array}{l}\mathrm{OR}=0.95 \\
(0.78-1.15) \\
\end{array}$ & discontinue warfarin or antiplatelets & Previous stroke & $\begin{array}{l}\text { Hughes et al. } \\
\text { (2004) [18] }\end{array}$ \\
\hline \multirow[t]{2}{*}{$\begin{array}{l}\text { Non-white } 0 \% \text { (vs }>0 \% \text { to }< \\
5 \% \text { ) }\end{array}$} & - & $\begin{array}{l}\mathrm{OR}=0.74 \\
(0.57-0.96)\end{array}$ & initiate warfarin or antiplatelets & Previous stroke & $\begin{array}{l}\text { Hughes et al. } \\
\text { (2004) [18] }\end{array}$ \\
\hline & 0 & $\begin{array}{l}\mathrm{OR}=1.17 \\
(0.93-1.46)\end{array}$ & discontinue warfarin or antiplatelets & Previous stroke & $\begin{array}{l}\text { Hughes et al. } \\
\text { (2004) [18] }\end{array}$ \\
\hline \multirow[t]{2}{*}{$\begin{array}{l}\text { Ownership status for profit } \\
\text { (vs non-profit) }\end{array}$} & 0 & $\begin{array}{l}\mathrm{OR}=0.90 \\
(0.76-1.07)\end{array}$ & initiate warfarin or antiplatelets & Previous stroke & $\begin{array}{l}\text { Hughes et al. } \\
\text { (2004) [18] }\end{array}$ \\
\hline & 0 & $\begin{array}{l}\mathrm{OR}=0.90 \\
(0.77-1.05)\end{array}$ & discontinue warfarin or antiplatelets & Previous stroke & $\begin{array}{l}\text { Hughes et al. } \\
\text { (2004) [18] }\end{array}$ \\
\hline \multirow[t]{2}{*}{$\begin{array}{l}\text { Ownership status } \\
\text { government (vs non-profit) }\end{array}$} & 0 & $\begin{array}{l}\mathrm{OR}=0.86 \\
(0.64-1.17)\end{array}$ & initiate warfarin or antiplatelets & Previous stroke & $\begin{array}{l}\text { Hughes et al. } \\
\text { (2004) [18] }\end{array}$ \\
\hline & 0 & $\begin{array}{l}\mathrm{OR}=0.99 \\
(0.76-1.29)\end{array}$ & discontinue warfarin or antiplatelets & Previous stroke & $\begin{array}{l}\text { Hughes et al. } \\
\text { (2004) [18] }\end{array}$ \\
\hline \multirow[t]{2}{*}{ Part of a chain } & + & $\begin{array}{l}\mathrm{OR}=1.20 \\
(1.01-1.42)\end{array}$ & initiate warfarin or antiplatelets & Previous stroke & $\begin{array}{l}\text { Hughes et al. } \\
\text { (2004) [18] }\end{array}$ \\
\hline & - & $\begin{array}{l}\mathrm{OR}=0.85 \\
(0.73-0.99)\end{array}$ & discontinue warfarin or antiplatelets & Previous stroke & $\begin{array}{l}\text { Hughes et al. } \\
\text { (2004) [18] }\end{array}$ \\
\hline \multirow[t]{2}{*}{$\begin{array}{l}\text { Payment source \% Medicaid } \\
\text { (per } 10 \text { unit increase) }\end{array}$} & 0 & $\begin{array}{l}\mathrm{OR}=0.98 \\
(0.91-1.05)\end{array}$ & discontinue warfarin or antiplatelets & Previous stroke & $\begin{array}{l}\text { Hughes et al. } \\
\text { (2004) [18] }\end{array}$ \\
\hline & 0 & $\begin{array}{l}\mathrm{OR}=0.95 \\
(0.88-1.03)\end{array}$ & initiate warfarin or antiplatelets & Previous stroke & $\begin{array}{l}\text { Hughes et al. } \\
\text { (2004) [18] }\end{array}$ \\
\hline \multirow[t]{2}{*}{$\begin{array}{l}\text { Payment source \% other-pay } \\
\text { (per } 10 \text { unit increase) }\end{array}$} & 0 & $\begin{array}{l}\mathrm{OR}=0.94 \\
(0.87-1.01)\end{array}$ & discontinue warfarin or antiplatelets & Previous stroke & $\begin{array}{l}\text { Hughes et al. } \\
\text { (2004) [18] }\end{array}$ \\
\hline & 0 & $\begin{array}{l}\mathrm{OR}=0.97 \\
(0.89-1.05)\end{array}$ & initiate warfarin or antiplatelets & Previous stroke & $\begin{array}{l}\text { Hughes et al. } \\
\text { (2004) [18] }\end{array}$ \\
\hline Presence of a RN/LPN & 0 & $\begin{array}{l}\mathrm{OR}=0.74 \\
(\mathrm{Cl} \text { not reported })\end{array}$ & use of warfarin or antiplatelets & Previous stroke & $\begin{array}{l}\text { Sloane et al. } \\
\text { (2004) [13] }\end{array}$ \\
\hline
\end{tabular}


Table 2 Association of factors with warfarin prescribing (Continued)

\begin{tabular}{|c|c|c|c|c|c|c|}
\hline & \multirow[t]{2}{*}{ Size $\leq 80$ (vs 81-199) } & 0 & $\begin{array}{l}\mathrm{OR}=1.01 \\
(0.81-1.26)\end{array}$ & initiate warfarin or antiplatelets & Previous stroke & $\begin{array}{l}\text { Hughes et al. } \\
\text { (2004) [18] }\end{array}$ \\
\hline & & 0 & $\begin{array}{l}\mathrm{OR}=0.92 \\
(0.77-1.11)\end{array}$ & discontinue warfarin or antiplatelets & Previous stroke & $\begin{array}{l}\text { Hughes et al. } \\
\text { (2004) [18] }\end{array}$ \\
\hline & \multirow[t]{2}{*}{ Size $\geq 200$ (vs 81 to 199) } & 0 & $\begin{array}{l}\mathrm{OR}=1.17 \\
(0.99-1.39)\end{array}$ & discontinue warfarin or antiplatelets & Previous stroke & $\begin{array}{l}\text { Hughes et al. } \\
\text { (2004) [18] }\end{array}$ \\
\hline & & 0 & $\begin{array}{l}\mathrm{OR}=1.08 \\
(0.90-1.30)\end{array}$ & initiate warfarin or antiplatelets & Previous stroke & $\begin{array}{l}\text { Hughes et al. } \\
\text { (2004) [18] }\end{array}$ \\
\hline & \multirow[t]{2}{*}{ Special care unit } & 0 & $\begin{array}{l}\mathrm{OR}=1.15 \\
(0.83-1.59)\end{array}$ & initiate warfarin or antiplatelets & Previous stroke & $\begin{array}{l}\text { Hughes et al. } \\
\text { (2004) [18] }\end{array}$ \\
\hline & & + & $\begin{array}{l}\mathrm{OR}=1.33 \\
(1.02-1.73)\end{array}$ & discontinue warfarin or antiplatelets & Previous stroke & $\begin{array}{l}\text { Hughes et al. } \\
\text { (2004) [18] }\end{array}$ \\
\hline & \multirow[t]{2}{*}{$\begin{array}{l}\text { Staff resources any full-time } \\
\text { physicians }\end{array}$} & - & $\begin{array}{l}\mathrm{OR}=0.76 \\
(0.63-0.92)\end{array}$ & initiate warfarin or antiplatelets & Previous stroke & $\begin{array}{l}\text { Hughes et al. } \\
\text { (2004) [18] }\end{array}$ \\
\hline & & 0 & $\begin{array}{l}\mathrm{OR}=1.05 \\
(0.89-1.24)\end{array}$ & discontinue warfarin or antiplatelets & Previous stroke & $\begin{array}{l}\text { Hughes et al. } \\
\text { (2004) [18] }\end{array}$ \\
\hline & \multirow[t]{2}{*}{ Staff resources (contract) } & 0 & $\begin{array}{l}\mathrm{OR}=1.04 \\
(0.89-1.20)\end{array}$ & initiate warfarin or antiplatelets & Previous stroke & $\begin{array}{l}\text { Hughes et al. } \\
\text { (2004) [18] }\end{array}$ \\
\hline & & 0 & $\begin{array}{l}\mathrm{OR}=1.02 \\
(0.89-1.17)\end{array}$ & discontinue warfarin or antiplatelets & Previous stroke & $\begin{array}{l}\text { Hughes et al. } \\
\text { (2004) [18] }\end{array}$ \\
\hline & \multirow[t]{2}{*}{$\begin{array}{l}\text { Staff resources (physician } \\
\text { extenders) }\end{array}$} & + & $\begin{array}{l}\mathrm{OR}=1.21 \\
(1.0-1.47)\end{array}$ & $\begin{array}{l}\text { discontinue warfarin } \\
\text { or antiplatelets }\end{array}$ & Previous stroke & $\begin{array}{l}\text { Hughes et al. } \\
\text { (2004) [18] }\end{array}$ \\
\hline & & 0 & $\begin{array}{l}\mathrm{OR}=1.08 \\
(0.87-1.34)\end{array}$ & initiate warfarin or antiplatelets & Previous stroke & $\begin{array}{l}\text { Hughes et al. } \\
\text { (2004) [18] }\end{array}$ \\
\hline & Traditional facility (vs small) & 0 & $\begin{array}{l}\mathrm{OR}=0.78 \\
(\mathrm{Cl} \text { not reported })\end{array}$ & use of warfarin or antiplatelets & Previous stroke & $\begin{array}{l}\text { Sloane et al. } \\
\text { (2004) [13] }\end{array}$ \\
\hline & Weekly physician visits & 0 & $\begin{array}{l}\mathrm{OR}=0.94 \\
(\mathrm{Cl} \text { notreported })\end{array}$ & use of warfarin or antiplatelets & Previous stroke & $\begin{array}{l}\text { Sloane et al. } \\
\text { (2004) [13] }\end{array}$ \\
\hline \multirow[t]{5}{*}{ Gender } & \multirow[t]{5}{*}{ Female } & 0 & not reported & use of warfarin & AF & $\begin{array}{l}\text { Gurwitz et al. } \\
\text { (1997) [8] }\end{array}$ \\
\hline & & - & $\begin{array}{l}\mathrm{OR}=0.94 \\
(0.90-0.98)\end{array}$ & use of warfarin orantiplatelets & Previous stroke & $\begin{array}{l}\text { Quilliam et al. } \\
\text { (2001) [12] }\end{array}$ \\
\hline & & 0 & $\begin{array}{l}\mathrm{OR}=0.99 \\
(0.87-1.13)\end{array}$ & initiate warfarin orantiplatelets & Previous stroke & $\begin{array}{l}\text { Hughes et al. } \\
\text { (2004) [18] }\end{array}$ \\
\hline & & 0 & $\begin{array}{l}\mathrm{OR}=1.00 \\
(0.89-1.13)\end{array}$ & discontinue warfarinor antiplatelets & Previous stroke & $\begin{array}{l}\text { Hughes et al. } \\
\text { (2004) [18] }\end{array}$ \\
\hline & & 0 & $\begin{array}{l}\text { OR }=0.81 \\
(\mathrm{Cl} \text { not reported) }\end{array}$ & use of warfarin orantiplatelets & Previous stroke & $\begin{array}{l}\text { Sloane et al. } \\
\text { (2004) [13] }\end{array}$ \\
\hline \multirow[t]{2}{*}{$\begin{array}{l}\text { Physical } \\
\text { Function }\end{array}$} & Substantial mobility & 0 & not reported & use of warfarin & $\mathrm{AF}$ & $\begin{array}{l}\text { Gurwitz et al. } \\
\text { (1997) [8] }\end{array}$ \\
\hline & Mild impairment & 0 & not reported & use of warfarin & $\mathrm{AF}$ & $\begin{array}{l}\text { Gurwitz et al. } \\
\text { (1997) [8] }\end{array}$ \\
\hline
\end{tabular}


Table 2 Association of factors with warfarin prescribing (Continued)

\begin{tabular}{|c|c|c|c|c|c|c|}
\hline & Intermediate mobility & 0 & not reported & use of warfarin & AF & $\begin{array}{l}\text { Gurwitz et al. } \\
\text { (1997) [8] }\end{array}$ \\
\hline & \multirow[t]{4}{*}{ Moderate impairment } & 0 & $\begin{array}{l}\mathrm{OR}=0.95 \\
(0.75-1.20)\end{array}$ & discontinue warfarin or antiplatelets & Previous stroke & $\begin{array}{l}\text { Hughes et al. } \\
\text { (2004) [18] }\end{array}$ \\
\hline & & 0 & $\begin{array}{l}\mathrm{OR}=0.90 \\
(0.70-1.16)\end{array}$ & initiate warfarin or antiplatelets & Previous stroke & $\begin{array}{l}\text { Hughes et al. } \\
\text { (2004) [18] }\end{array}$ \\
\hline & & 0 & not reported & use of warfarin & AF & $\begin{array}{l}\text { Gurwitz et al. } \\
\text { (1997) [8] }\end{array}$ \\
\hline & & 0 & $\begin{array}{l}\mathrm{OR}=1.03 \\
(0.95-1.11)\end{array}$ & use of warfarin or antiplatelets & Previous stroke & $\begin{array}{l}\text { Quilliam et al. } \\
\text { (2001) [12] }\end{array}$ \\
\hline & \multirow[t]{4}{*}{ Dependent } & - & $\begin{array}{l}\mathrm{OR}=0.69 \\
(0.64-0.75)\end{array}$ & use of warfarin or antiplatelets & Previous stroke & $\begin{array}{l}\text { Quilliam et al. } \\
\text { (2001) [12] }\end{array}$ \\
\hline & & - & $\begin{array}{l}\mathrm{OR}=0.73 \\
(0.56-0.96)\end{array}$ & $\begin{array}{l}\text { initiate warfarin or } \\
\text { antiplatelets }\end{array}$ & Previous stroke & $\begin{array}{l}\text { Hughes et al. } \\
\text { (2004) [18] }\end{array}$ \\
\hline & & 0 & $\begin{array}{l}\mathrm{OR}=0.99 \\
(0.79-1.25)\end{array}$ & discontinue warfarin or antiplatelets & Previous stroke & $\begin{array}{l}\text { Hughes et al. } \\
\text { (2004) [18] }\end{array}$ \\
\hline & & 0 & $\begin{array}{l}\mathrm{OR}=1.21 \\
(\mathrm{Cl} \text { notreported })\end{array}$ & use of warfarin or antiplatelets & Previous stroke & $\begin{array}{l}\text { Sloane et al. } \\
\text { (2004) [13] }\end{array}$ \\
\hline & Severe impairment & 0 & not reported & use of warfarin & $\mathrm{AF}$ & $\begin{array}{l}\text { Gurwitz et al. } \\
\text { (1997) [8] }\end{array}$ \\
\hline \multirow[t]{10}{*}{$\begin{array}{l}\text { Race/ } \\
\text { ethnicity }\end{array}$} & \multirow[t]{3}{*}{ American Indian } & 0 & $\begin{array}{l}\mathrm{OR}=1.00 \\
(0.70-1.43)\end{array}$ & discontinue warfarin or antiplatelets & Previous stroke & $\begin{array}{l}\text { Hughes et al. } \\
\text { (2004) [18] }\end{array}$ \\
\hline & & 0 & Difference $=-0.8(-8.9$ to 7.3$)$ & $\begin{array}{l}\text { prevalence difference from non-Hispanic white } \\
\text { for receiving warfarin or antiplatelets }\end{array}$ & $\begin{array}{l}\text { Recent ischemic } \\
\text { stroke }\end{array}$ & $\begin{array}{l}\text { Christian et al. } \\
\text { (2003) [17] }\end{array}$ \\
\hline & & 0 & $\begin{array}{l}\mathrm{OR}=1.47 \\
(0.98-2.20)\end{array}$ & initiate warfarin or antiplatelets & Previous stroke & $\begin{array}{l}\text { Hughes et al. } \\
\text { (2004) [18] }\end{array}$ \\
\hline & \multirow[t]{3}{*}{ Asian/Pacific islander } & 0 & $\begin{array}{l}\text { Difference }=-5.2 \\
(-18.1 \text { to } 7.8)\end{array}$ & $\begin{array}{l}\text { prevalencedifference from non-Hispanic white for } \\
\text { receiving warfarin or antiplatelets }\end{array}$ & Recentischemicstroke & $\begin{array}{l}\text { Christian et al. } \\
\text { (2003) [17] }\end{array}$ \\
\hline & & 0 & $\begin{array}{l}\mathrm{OR}=0.71 \\
(0.42-1.21)\end{array}$ & initiate warfarin or antiplatelets & Previous stroke & $\begin{array}{l}\text { Hughes et al. } \\
\text { (2004) [18] }\end{array}$ \\
\hline & & - & $\begin{array}{l}\mathrm{OR}=0.44 \\
(0.23-0.83)\end{array}$ & discontinue warfarin or antiplatelets & Previous stroke & $\begin{array}{l}\text { Hughes et al. } \\
\text { (2004) [18] }\end{array}$ \\
\hline & Black & - & $\begin{array}{l}\mathrm{OR}=0.80 \\
(0.75-0.85)\end{array}$ & use of warfarin or antiplatelets & Previous stroke & $\begin{array}{l}\text { Quilliam et al. } \\
\text { (2001) [12] }\end{array}$ \\
\hline & \multirow[t]{3}{*}{ Hispanic } & 0 & $\begin{array}{l}\text { Difference }=-7.6 \\
(-17.6 \text { to } 2.2)\end{array}$ & $\begin{array}{l}\text { prevalence difference from non-Hispanic white } \\
\text { for receiving warfarin or antiplatelets }\end{array}$ & $\begin{array}{l}\text { Recent } \\
\text { ischemic } \\
\text { stroke }\end{array}$ & $\begin{array}{l}\text { Christian et al. } \\
\text { (2003) [17] }\end{array}$ \\
\hline & & 0 & $\begin{array}{l}\mathrm{OR}=0.81 \\
(0.51-1.29)\end{array}$ & initiate warfarin or antiplatelets & $\begin{array}{l}\text { Previous } \\
\text { stroke }\end{array}$ & $\begin{array}{l}\text { Hughes et al. } \\
\text { (2004) [18] }\end{array}$ \\
\hline & & 0 & $\begin{array}{l}\mathrm{OR}=1.01 \\
(0.62-1.65)\end{array}$ & discontinue warfarin or antiplatelets & Previous stroke & $\begin{array}{l}\text { Hughes et al. } \\
\text { (2004) [18] }\end{array}$ \\
\hline
\end{tabular}


Table 2 Association of factors with warfarin prescribing (Continued)

\begin{tabular}{|c|c|c|c|c|c|c|}
\hline & \multirow[t]{3}{*}{ Non- Hispanic black } & - & $\begin{array}{l}\mathrm{OR}=0.62 \\
(0.49-0.78)\end{array}$ & initiate warfarin or antiplatelets & Previous stroke & $\begin{array}{l}\text { Hughes et al. } \\
\text { (2004) [18] }\end{array}$ \\
\hline & & 0 & $\begin{array}{l}\mathrm{OR}=1.03 \\
(0.86-1.24)\end{array}$ & discontinue warfarin or antiplatelets & Previous stroke & $\begin{array}{l}\text { Hughes et al. } \\
\text { (2004) [18] }\end{array}$ \\
\hline & & - & $\begin{array}{l}\text { Difference }=-7.6 \\
(-11.2 \text { to }-3.9)\end{array}$ & $\begin{array}{l}\text { prevalence difference from non-Hispanic white } \\
\text { for receiving warfarin or antiplatelets }\end{array}$ & $\begin{array}{l}\text { Recent ischemic } \\
\text { stroke }\end{array}$ & $\begin{array}{l}\text { Christian et al } \\
\text { (2003) [17] }\end{array}$ \\
\hline & Other & 0 & $\begin{array}{l}\mathrm{OR}=0.95 \\
(0.86-1.04)\end{array}$ & use of warfarin or antiplatelets & Previous stroke & $\begin{array}{l}\text { Quilliam et al. } \\
\text { (2001) [12] }\end{array}$ \\
\hline & White & 0 & $\begin{array}{l}\mathrm{OR}=0.69 \\
(\mathrm{Cl} \text { not reported })\end{array}$ & use of warfarin or antiplatelets & Previous stroke & $\begin{array}{l}\text { Sloane et al. } \\
\text { (2004) [13] }\end{array}$ \\
\hline \multirow[t]{5}{*}{ Stroke risk } & 1 risk factor & 0 & $\begin{array}{l}\mathrm{OR}=1.44 \\
(0.52-4.03)\end{array}$ & use of warfarin & AF & $\begin{array}{l}\text { McCormick et } \\
\text { al. (2001) [11] }\end{array}$ \\
\hline & 2 risk factors & 0 & $\begin{array}{l}\mathrm{OR}=2.44 \\
(0.93-6.39)\end{array}$ & use of warfarin & AF & $\begin{array}{l}\text { McCormick et } \\
\text { al. (2001) [11] }\end{array}$ \\
\hline & 3 risk factors & 0 & $\begin{array}{l}\mathrm{OR}=2.37 \\
(0.90-6.20)\end{array}$ & use of warfarin & AF & $\begin{array}{l}\text { McCormick et } \\
\text { al. (2001) [11] }\end{array}$ \\
\hline & $\geq 4$ risk factors & 0 & $\begin{array}{l}\mathrm{OR}=2.50 \\
(0.90-6.95)\end{array}$ & use of warfarin & AF & $\begin{array}{l}\text { McCormick et } \\
\text { al. (2001) [11] }\end{array}$ \\
\hline & High risk & 0 & $\begin{array}{l}\mathrm{OR}=1.49 \\
(0.93-2.36)\end{array}$ & use of warfarin & AF & $\begin{array}{l}\text { Lau et al. } \\
\text { (2004)[10] }\end{array}$ \\
\hline
\end{tabular}

$\mathrm{AF}$, atrial fibrillation; $\mathrm{Cl}$, confidence interval; $\mathrm{OR}$, odds ratio 
However studies of residents with AF [10] and stroke survivors $[13,18]$, respectively, found no significant correlation between age $\geq 85$ years and use of these agents. Hughes et al. [18] evaluated stroke survivors in their first year after nursing home admission: residents $\geq 85$ years were most likely to discontinue warfarin or antiplatelet therapy $(\mathrm{OR}=1.23,95 \% \mathrm{CI}=1.05-1.43)$.

\section{Dementia and severe cognitive impairment}

Gurwitz et al. [8] reported that AF residents with dementia were less likely than those without it to receive warfarin therapy $(\mathrm{OR}=0.59,95 \% \mathrm{CI}=0.38-0.90)$. Quilliam et al. [12] further found that among residents who were stroke survivors, those with Alzheimer's disease $(\mathrm{OR}=$ $0.77,95 \% \mathrm{CI}=0.70-0.85)$ or dementia $(\mathrm{OR}=0.84,95 \%$ $\mathrm{CI}=0.80-0.88)$ were less likely to receive warfarin or antiplatelets; the likelihood of anticoagulant or antiplatelet therapy also decreased among residents with moderate $(\mathrm{OR}=0.93,95 \% \mathrm{CI}=0.88-0.97)$ or severe $(\mathrm{OR}=0.63$, $95 \% \mathrm{CI}=0.60-0.67)$ cognitive impairment [12]. Hughes et al. [18] also found that stroke survivors with severe cognitive impairment were less likely to initiate such therapy $(\mathrm{OR}=0.64,95 \% \mathrm{CI}=0.52-0.80)$. In contrast, Sloane et al. [13] found no significant association between severe cognitive impairment and use of warfarin or antiplatelets in stroke survivors.

\section{Physical functioning}

Both Quilliam et al. [12] $(\mathrm{OR}=0.69,95 \% \mathrm{CI}=0.64-0.75)$ and Hughes et al. [18] $(\mathrm{OR}=0.73,95 \% \mathrm{CI}=0.56-0.96)$ found that stroke survivors who had dependent physical function were less likely to receive warfarin or antiplatelets than those with independent function. However, Sloane et al. [13] found no significant association between physical dependency and receiving these agents among stroke survivors, and Gurwitz et al. [8] found no significant association between severe physical impairment and the use of warfarin in LTC residents with AF.

\section{Bleeding risk factors}

Abdel Latif et al. [7] found a negative association ( $\mathrm{OR}=$ $0.18,95 \% \mathrm{CI}=0.03-0.91$ ) between previous gastrointestinal (GI) bleed and warfarin use in residents with AF. Quilliam et al. [12] also found a negative relationship $(\mathrm{OR}=0.57,95 \% \mathrm{CI}=0.52-0.62)$ between GI bleeding and warfarin or antiplatelet use in stroke survivors. In that study, Quilliam et al. [12] also found a negative association $(\mathrm{OR}=0.64,95 \% \mathrm{CI}=0.58-0.71)$ between peptic ulcer disease and these agents, although Lau et al. [10] found no significant association between peptic ulcer disease and warfarin use in AF. Evaluating bleeding risk factors among AF residents, Lau et al. [10] observed no significant association between warfarin treatment and overall bleeding risk or any single risk factor for bleeding, with the exception of recent surgery. However, McCormick et al. [11] reported that the odds of warfarin treatment were significantly lower $(\mathrm{OR}=0.51,95 \% \mathrm{CI}=$ 0.29-0.94) for residents with $\mathrm{AF}$ and $\geq 2$ bleeding risk factors.

\section{Race/ethnicity}

Among residents with a history of stroke, four studies noted an association between race/ethnicity and being prescribed warfarin or antiplatelet therapy. Christian et al. [17] found that non-Hispanic blacks with a recent hospitalization for ischemic stroke and an indication for warfarin received warfarin less often (7.6\% lower rate) than nonHispanic white residents. In a study by Hughes et al. [18], in the year after nursing home admission, non-Hispanic black stroke survivors were less likely than non-Hispanic whites $(\mathrm{OR}=0.62,95 \% \mathrm{CI}=0.49-0.78)$ to be initiated on warfarin or antiplatelet therapy. Quilliam et al. [12] found that black stroke survivors were less likely than whites $(\mathrm{OR}=0.80,95 \% \mathrm{CI}=0.75-0.85)$ to receive warfarin or any antiplatelets. Although Abdel-Latif et al. [7] reported that non-Caucasian stroke survivors with AF were less likely than Caucasians to be prescribed warfarin therapy, these findings appear to be bivariate and were not significant in their multivariate model (OR was not reported).

\section{LTC facility}

For residents within residential care/assisted living facilities, Sloane et al. [13] explored the association between resident and facility characteristics and warfarin or antiplatelet prescribing for stroke survivors. Although bivariate analysis found that several facility characteristics, including larger facilities and those with registered nurses or licensed practical nurses, were associated with nonprescribing, multivariate analysis found no independent association for resident or facility characteristics. After adjusting for facility and resident characteristics, Hughes et al. [18] found that LTC facilities with white-only residents $(\mathrm{OR}=0.74,95 \% \mathrm{CI}=\mathrm{NA})$ or the presence of fulltime physicians $(\mathrm{OR}=0.76,95 \% \mathrm{CI}=0.63-0.93)$ were less likely, and that those that were part of a chain $(\mathrm{OR}=$ $1.20,95 \% \mathrm{CI}=1.01-1.42$ ), were more likely, to initiate warfarin or antiplatelets in stroke survivors. Moreover, facilities with $>10 \%$ non-white residents $(\mathrm{OR}=1.22,95 \%$ $\mathrm{CI}=1.03-1.43)$, in an urban location $(\mathrm{OR}=1.38,95 \%$ $\mathrm{CI}=1.16-1.65)$, having physician extenders on staff $(\mathrm{OR}=1.21,95 \% \mathrm{CI}=1.0-1.47)$, or having special care units $(\mathrm{OR}=1.33,95 \% \mathrm{CI}=1.02-1.73)$ were more likely to discontinue active warfarin or antiplatelet therapy.

\section{Quality assessment}

Quality assessment ratings are listed for each of the 14 studies in Table 1. Methodological quality of each study was adequate for all but four areas. One or more limitations or concerns were noted for nine studies $[7,9,11,13,17,18,21,24,25]$. These included failing to adequately account for potential confounders, failing to consistently describe statistical error for the point estimates 
reported or to adequately model the relationship between stroke and bleeding risk with warfarin use. In the last case, typical problems noted were either omitting risk factors or else failing to score risks using a validated scoring method or consensus guidelines. Four studies $[7,9,17,21]$ had small sample sizes: subject counts for these studies would not have been able to support a finding of $95 \%$ significance for an OR of 1.5. Four studies [17-19,24] had limitations in length of follow-up.

\section{Prescriber Attitudes and Concerns about Warfarin Use}

Two studies $(n=289)[27,29]$ explored physician attitudes toward warfarin prescribing using case-study questionnaires targeted to physicians (Table 3), while one study $(\mathrm{n}=91)$ [28] (Table 3$)$ explored physician attitudes regarding specialized warfarin services. Dharmarajan et al. [27] evaluated respondent decisions regarding the use of warfarin therapy in the hypothetical case of a white 87-year-old female LTC resident with a history of Alzheimer's disease, surgery for a hip fracture, and AF. The resident, who was wheelchair-bound and dependent for most activities of daily living, had swelling on her forehead from a recent fall, but was negative for fracture on radiological examination. A large majority of responding physicians (85\%) believed that long-term warfarin therapy was not indicated for this patient. However, most $(88 \%)$ said they would prescribe an antiplatelet agent. The reasons most commonly cited for not prescribing warfarin were risk of falls (98\%), dementia (40\%), and limited life expectancy (32\%).

In a similar study, Monette et al. [29] used two case studies - a 94-year old male with chronic AF and co-morbid CHF but having independent physical function and no fall history, and an 80-year old female stroke survivor with AF and CHF who also had hemiplegia, dysarthria, and a recent fall history-to assess physicians' knowledge and attitudes regarding the use of warfarin for stroke prevention in residents with AF. Only $47 \%$ of respondents believed that the benefits of warfarin therapy greatly outweighed the risks in this setting; the remainder indicated that benefits outweighed the risks only slightly (34\%) or that the risks outweighed the benefits (19\%). Contraindications to warfarin use that were cited most frequently included excessive risk of falls (71\%), history of GI bleeding $(71 \%)$, history of other non-central nervous system (CNS) bleeding (36\%), and history of cerebrovascular hemorrhage (25\%) [29]. Geriatricians were significantly more likely than other physicians to recommend warfarin in the older but more functional case-study resident.

Harrold et al. [28] explored physician attitudes regarding the use of specialized warfarin services in the LTC setting. The majority of physicians agreed that a warfarin service could reduce the workload on physicians and increase the percent of time that residents receiving warfarin are maintained in the target therapeutic range. However, most physicians did not believe that such a service would reduce the risk of warfarin-related bleeding. Only about half of respondents indicated that they might use a warfarin service for managing their residents on warfarin.

\section{Quality assessment}

Although the three physician surveys described above were innovative, their methodological quality was somewhat low in critical areas. While all three studies introduced new self-administered questionnaires, only one analyzed data regarding non-responders [28], while two $[27,28]$ did not mention steps taken to develop content validity. None of the surveys provided details regarding analysis of item response for the purpose of assessing construct validity. Finally, all three studies had limitations with analysis: failure either to adequately report statistical error or to cross-tabulate responses with subject attributes.

\section{Warfarin Management and Monitoring International normalized ratio (INR)}

The quality of warfarin management and monitoring (Table 4 Part A) was measured in seven studies ( $\mathrm{n}=$ $10,718)[8,9,11,22,25,30,31]$, six of which $(n=10,681)$ $[8,9,11,22,25,30]$ evaluated the percentage of time or person-days spent by residents in therapeutic range, based on INR results. In these six studies, INR levels were in the target range (2.0-3.0) for a mean $48 \%$ of the time (range $=37-55 \%$ ). Four of these studies $[8,11,22,25]$ also reported percentage of time or person-days in subtherapeutic or supratherapeutic ranges. INR levels were in the subtherapeutic range $(<2.0)$ for a mean of $38 \%$ of the time (range $=35-45 \%$ ) and in the supratherapeutic range (>3.0) for a mean of $14 \%$ of the time (range $=11-16 \%$ ). One study, Karki et al. [31], reported only mean INRs for residents and only for those whose INR values indicated either adequate or poor INR control.

Two studies that evaluated the effectiveness of warfarin medication management systems $[23,24](n=175$, Table 4 Part B) found post-interventional time in therapeutic range considerably higher than reported in the six studies above. Papaioannou et al. [24] studied the effects of an electronic decision-support system for warfarin dosing and found that time in therapeutic range was 65\% (pre-intervention) to $69 \%$ (post-intervention; the post-interventional change was non-significant). In a study of warfarin management by nurse practitioners, Allen et al. [23] measured $85 \%$ of INR draws within therapeutic range. These measurements were post-intervention only; no pre-intervention or control results were reported.

\section{Factors associated with INR range}

Three studies [22,30,31] (Table 4 Part A) evaluated the association of resident characteristics with INR ( $\mathrm{n}=$ 302). Aspinall et al. [30] noted that residents who began 


\section{Table 3 Prescriber attitudes and concerns with warfarin use}

\begin{tabular}{|c|c|c|c|c|c|}
\hline Study & $\begin{array}{l}\text { Study objective, (intervention/ } \\
\text { exposure and outcomes) }\end{array}$ & Study design, data source & $\begin{array}{l}\text { Study population, study setting, } \\
\text { time period }\end{array}$ & Results & $\begin{array}{l}\text { Quality assessment, } \\
\text { funding source }\end{array}$ \\
\hline $\begin{array}{l}\text { Dharmarajan } \\
\text { et al. (2006) } \\
\text { [27] }\end{array}$ & $\begin{array}{l}\text { To evaluate the decision whether or } \\
\text { not to anticoagulate among } \\
\text { physicians in practice and in various } \\
\text { levels of training (residents and } \\
\text { fellows) for a specific, yet not } \\
\text { unusual, case scenario in the nursing } \\
\text { home }\end{array}$ & 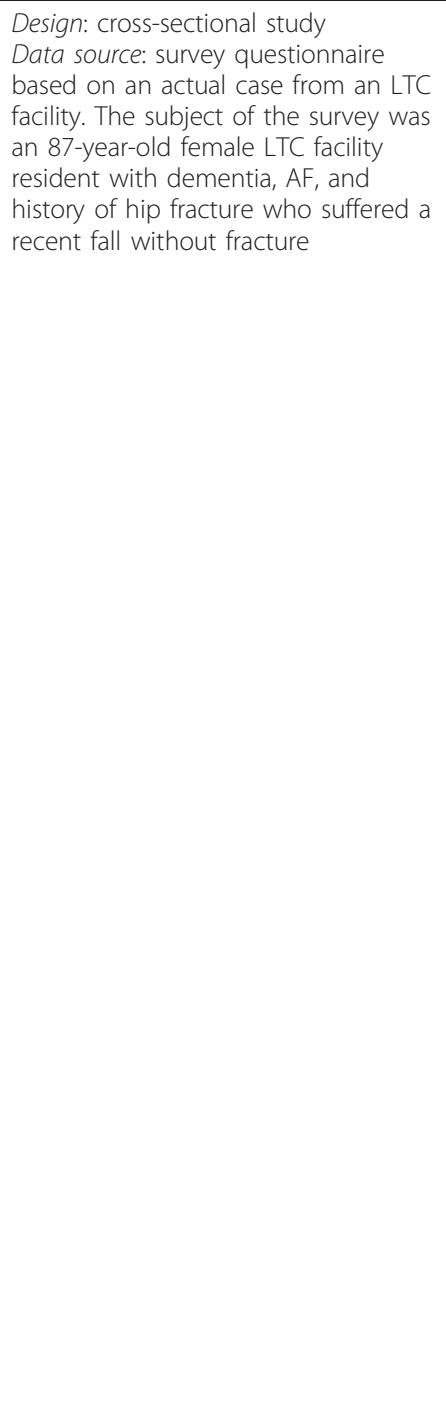 & $\begin{array}{l}\text { Population: } 107 \text { completed surveys } \\
\text { were returned from } 49 \text { residents, } 20 \\
\text { fellows, and } 38 \text { attending } \\
\text { physicians } \\
\text { Setting: a university teaching } \\
\text { hospital in the Bronx, NY (US) } \\
\text { Time period: survey dates not } \\
\text { specified }\end{array}$ & $\begin{array}{l}\text { The majority of physicians ( } 85 \%) \\
\text { thought that long-term } \\
\text { anticoagulation therapy was not } \\
\text { indicated in the case patient. } \\
\text { However, most ( } 88 \% \text { ) said they } \\
\text { would provide an antiplatelet agent } \\
\text { (78\% aspirin, } 20 \% \text { clopidogrel). The } \\
\text { most cited reasons for not providing } \\
\text { anticoagulation were risk of falls } \\
(98 \%) \text {, dementia (40\%), and short life } \\
\text { expectancy (32\%). } 92 \% \text { of } \\
\text { respondents said the patient was a } \\
\text { candidate for short-term } \\
\text { anticoagulation therapy. Responses } \\
\text { to the questions were similar for all } \\
\text { physicians (or faculty) irrespective of } \\
\text { level of training or years in practice }\end{array}$ & $\begin{array}{l}\text { Quality assessment for } \\
\text { observational studies: } \\
\text { 1) Unbiased selection of } \\
\text { the cohort? Cannot be } \\
\text { determined; cohort } \\
\text { selection details not } \\
\text { provided; non-response } \\
\text { rate not disclosed } \\
\text { 2) Selection minimizes } \\
\text { baseline differences in } \\
\text { prognostic factors? Cannot } \\
\text { be determined } \\
\text { 3) Sample size calculated/ } \\
\text { 5\% difference? No } \\
\text { 4) Adequate description of } \\
\text { the cohort? No; details of } \\
\text { cohort other than practice } \\
\text { specialty were not } \\
\text { provided } \\
\text { 5) Validated method for } \\
\text { ascertaining exposure? No; } \\
\text { reliability concern since } \\
\text { limited to } 1 \text { case study; } \\
\text { content validity of case } \\
\text { study not described } \\
\text { 6) Validated method for } \\
\text { ascertaining clinical } \\
\text { outcomes? No; validation } \\
\text { assessment of response } \\
\text { choices not performed } \\
\text { 7) Outcome assessment } \\
\text { blind to exposure? NA } \\
\text { 8) Adequate follow-up } \\
\text { period? Yes; cross-sectional } \\
\text { 9) Completeness of follow- } \\
\text { up? Yes } \\
\text { 10) Analysis controls for } \\
\text { confounding? Partial; cross- } \\
\text { tabulations performed on } \\
\text { responses by specialty } \\
\text { 11) Analytic methods } \\
\text { appropriate? Yes } \\
\text { Funding: Geriatric } \\
\text { Medicine Fellowship } \\
\text { program }\end{array}$ \\
\hline
\end{tabular}


Harrold et al. To examine physician attitudes Design: cross-sectional study

(2002) [28] regarding the use of specialized Data source: survey questionnaire anticoagulation services in the LTC

setting $\begin{array}{ll}\text { Population: } 245 \text { physicians asked to } & \text { The majority of respondents agreed } \\ \text { participate in the survey; } 114(47 \%) & \text { or strongly agreed that an }\end{array}$ responded. 91 reported that they currently cared for residents in LTC facilities and thus completed the questionnaire

Setting: 21 LTC facilities in

Connecticut (US)

Time period: Nov 1999 - Jan 2000 or strongly agreed that an anticoagulation service would reduce the workload on physicians (76\%), therapeutic range (54\%). $53 \%$
The majority of respondents agreed Quality assessment for aursing home residents on warfarin 2) Selection minimizes baseline differences in disagreed or strongly disagreed with statements suggesting the this statements suggesting that this warfarin-related bleeding. $45 \%$ of respondents agreed with a statem that this service would intrude on physician decision-making. 53\% of the respondents said they might use an anticoagulation service for an anticoagulation service for managing the LTC patients on warfarin. The most desirable aspects of an anticoagulation service were surveillance for drug interactions $(65 \%)$, scheduling of laboratory tests $(48 \%)$, management of warfarin

dosing (45\%), and risk assessment for bleeding (40\%). The most frequently cited challenges to managing warfarin therapy in the nursing home setting were dealing with medications that interact with warfarin (59\%), keeping patients within target therapeutic range (53\%), and making dosage adjustments (30\%)
3) Sample size calculated/ 5\% difference? No 4) Adequate description of the cohort? Yes 5) Validated method for ascertaining exposure? No; minimal description of anticoagulation services provided

6) Validated method for ascertaining clinical outcomes? Validation of new questionnaire not reported

7) Outcome assessment blind to exposure? NA 8) Adequate follow-up period? Yes; cross-section 9) Completeness of followup? Yes

10) Analysis controls for confounding? No; cross tabulation with subject attributes not performed 11) Analytic methods appropriate? No; statistical error $(\mathrm{Cls})$ reported in only some findings

Funding: Centers for

Medicare and Medicaid

Services, Department of Health and Human Services; AHRQ 
Table 3 Prescriber attitudes and concerns with warfarin use (Continued)

\begin{tabular}{|c|c|c|c|c|c|}
\hline $\begin{array}{l}\text { Monette et } \\
\text { al. (1997) [29] }\end{array}$ & $\begin{array}{l}\text { To assess the knowledge and } \\
\text { attitudes of physicians regarding the } \\
\text { use of warfarin for stroke prevention } \\
\text { in patients with AF in LTC facilities }\end{array}$ & $\begin{array}{l}\text { Design: cross-sectional study } \\
\text { Data source: survey questionnaire of } \\
2 \text { clinical scenarios with substantial } \\
\text { contrasts in patient characteristics: } \\
\text { 1) } 94-y e a r \text { old male resident with } \\
\text { chronic AF, ischemic heart disease, } \\
\text { CHF and osteoarthritis, no history of } \\
\text { falls, independent in activities of daily } \\
\text { living; } \\
\text { 2) } 80-y e a r \text { old female with recent } \\
\text { stroke with resulting hemiplegia and } \\
\text { dysarthria, having chronic AF, CHF, } \\
\text { CAD, hypertension, diabetes, and } \\
\text { chronic renal insufficiency, with } \\
\text { cognitive deficits and entirely } \\
\text { nonambulatory }\end{array}$ & $\begin{array}{l}\text { Population: } 269 \text { physicians were } \\
\text { asked to participate in the survey; } \\
182(67.7 \%) \text { completed the } \\
\text { questionnaire } \\
\text { Setting: } 30 \text { LTC facilities located in } \\
\text { New England, Quebec, and Ontario } \\
\text { (US and Canada) } \\
\text { Time period: Feb } 1995 \text { to Jul } 1995\end{array}$ & $\begin{array}{l}\text { Only } 47 \% \text { of respondents indicated } \\
\text { that the benefits of warfarin greatly } \\
\text { outweigh the risks in this setting; the } \\
\text { remainder of physicians indicated } \\
\text { that benefits only slightly outweigh } \\
\text { the risks (34\%) or that risks outweigh } \\
\text { benefits (19\%). The most frequently } \\
\text { cited contraindications to warfarin } \\
\text { use were: excessive risk of falls ( } 71 \%) \text {, } \\
\text { history of Gl bleeding ( } 71 \%) \text {, history } \\
\text { of non-CNS bleeding (36\%), and } \\
\text { history of cerebrovascular } \\
\text { hemorrhage ( } 25 \%) \text {. Among the } 164 \\
\text { physicians who reported using the } \\
\text { INR to monitor warfarin therapy, } 27 \% \\
\text { indicated a target range with a lower } \\
\text { limit < } 2.0,71 \% \text { indicated a target } \\
\text { range between } 2.0 \text { and } 3.0 \text {, and } 2 \% \\
\text { indicated an upper limit }>3.0 \text {. } \\
\text { Among respondents who answered } \\
\text { questions about the clinical scenarios, } \\
\text { estimates of the risk of stroke } \\
\text { without warfarin therapy and the risk } \\
\text { of intracranial hemorrhage with } \\
\text { therapy varied widely }\end{array}$ & $\begin{array}{l}\text { Quality assessment for } \\
\text { observational studies: } \\
\text { 1) Unbiased selection of } \\
\text { the cohort? Yes } \\
\text { 2) Selection minimizes } \\
\text { baseline differences in } \\
\text { prognostic factors? No; } \\
\text { analysis of non-responders } \\
\text { was not performed } \\
\text { 3) Sample size calculated/ } \\
\text { 5\% difference? No } \\
\text { 4) Adequate description of } \\
\text { the cohort? Yes } \\
\text { 5) Validated method for } \\
\text { ascertaining exposure? Yes; } \\
\text { conducted pre-testing to } \\
\text { establish content validity } \\
\text { 6) Validated method for } \\
\text { ascertaining clinical } \\
\text { outcomes? No further } \\
\text { assessment validity } \\
\text { conducted for new } \\
\text { questionnaire } \\
\text { 7) Outcome assessment } \\
\text { blind to exposure? NA 8) } \\
\text { Adequate follow-up } \\
\text { period? Yes; cross-sectional } \\
\text { 9) Completeness of follow- } \\
\text { up? Yes } \\
\text { 10) Analysis controls for } \\
\text { confounding? Yes } \\
\text { 11) Analytic methods } \\
\text { appropriate? No; statistical } \\
\text { error (Cls) reported in only } \\
\text { some findings } \\
\text { Funding: Dupont Pharma }\end{array}$ \\
\hline
\end{tabular}

$\mathrm{AF}$, atrial fibrillation; $\mathrm{AHRQ}$, Agency for Healthcare Research and Quality; CAD, coronary artery disease; CHF, congestive heart failure; Cl confidence interval; CNS, central nervous system; Gl, gastrointestinal; INR, international normalized ratio; LTC, long-term care; NA not available. 
warfarin therapy before the study period and those who did not have a history of stroke were more likely to maintain INR values within the therapeutic range. Karki et al. [31] observed that a group of LTC residents with INR fluctuations > 0.99 between blood samplings received more medications known to interact with warfarin vs a group with INR fluctuations ranging from 0.50.99 . Verhovsek et al. [22] found that residents receiving interacting medications spent less time in therapeutic range. Time in therapeutic range varied significantly among prescribing physicians [22].

\section{Potential warfarin interactions}

The three studies cited above [22,30,31] (Table 4 Part A) also evaluated the use of potentially interacting medications among residents receiving warfarin for any condition $(n=302)$. Aspinall et al. [30] reported that $89 \%$ of residents were receiving a medication that potentially interacts with warfarin. The most common agents were omeprazole (51\% of residents), simvastatin (45\%), aspirin (34\%), citalopram (18\%), and levothyroxine (13\%). Karki et al. [31] reported that $46 \%$ of LTC residents were prescribed a potentially interacting agent during the study period. Verhovsek et al. [22] found that 79\% of residents were prescribed more than one warfarin-interacting medication during a 12-month period; most common were acetaminophen (40\% of residents), citalopram (25\%), aspirin (16\%), diltiazem (11\%), and simvastatin (10\%).

\section{Quality assessment}

Overall, in the nine warfarin management and monitoring studies described above (Table 4 Parts A and B), methodological quality was low to moderate. Low power was common: five studies $[9,22,23,30,31]$ had an insufficient number of subjects to find 95\% significance for an odds ratio of 1.5. Four studies [22-24,30] had either inadequate descriptions of resident follow-up or insufficient follow-up periods to achieve the stated study purpose. Seven studies $[9,11,22-25,31]$ had deficiencies either in adequately analyzing or reporting study findings or in accounting for potential confounders.

\section{Warfarin-related Adverse Events}

Two studies [25,26] (Table 5) sought to evaluate adverse warfarin-related events in the LTC population ( $\mathrm{n}=$ $17,429)$. In a study of 25 nursing homes, Gurwitz et al. [25] determined the combined overall rate of adverse warfarin-related events (18.8 per 100) and potential adverse warfarin-related events (6.6 per 100) to be 25.5 per 100 resident-months on warfarin therapy. Of the adverse warfarin-related events, $11 \%$ were deemed serious and $2 \%$ were life-threatening or fatal. Overall, 29\% of the adverse warfarin-related events were considered preventable; of the serious, life-threatening, and fatal events, over half (57\%) were considered preventable. Quilliam et al. [26] explored an association between warfarin and the antiplatelet agents (excluding clopidogrel, which was not yet available) and risk of hospitalization for bleeding among LTC residents. After adjustment for demographic characteristics and medications, use of warfarin, compared to no warfarin or antiplatelet medication, was associated with a significantly increased risk of hospitalization for bleeding. Recipients of warfarin plus aspirin were more likely to be hospitalized for a CNS bleeding event; recipients of warfarin alone were more likely to be hospitalized for a GI bleeding event.

\section{Quality assessment}

Except for limitations in one study, which neither adequately controlled for confounding nor explored the association of poor INR control with warfarin-related adverse events or resident characteristics [25], methodological quality for these two adverse event studies was acceptable.

\section{Discussion}

Results from this review show that AF, DVT, PE, and stroke prevention in residents without AF, account for nearly all warfarin use in the LTC setting [24,25]. Of these four, AF is the primary indication for warfarin use, accounting for the majority, or as many as three of every four residents receiving this agent in LTC [24,25].

\section{Suboptimal anticoagulation among patients with AF}

Current consensus guidelines, including those of the American College of Chest Physicians (ACCP) [32-34], American College of Cardiology/American Heart Association/European Society of Cardiology (ACC/AHA/ESC) [35], and the ESC alone [36], strongly support the use of warfarin in patients with AF who have one or more high risk factors or two or more moderate risk factors for stroke, especially among those not at high risk for bleeding. The American Medical Directors Association (AMDA) guidelines for stroke management in LTC, updated in 2011, also recommend warfarin as primary therapy for stroke prophylaxis in AF, but suggest that a systematic assessment of stroke and bleeding risk be performed prior to initiation of therapy [2]. Lau et al. in this review found that nearly all LTC residents with AF were at high risk for stroke simply because $88 \%$ of residents were $\geq 75$ years of age[10].

Current AMDA guidelines cite a general low use of warfarin in residents with AF who have no contraindications for its use [2]. Evidence from five LTC studies in our review suggests a pattern of improving but still low rates of warfarin use in AF: among LTC residents with AF studied since 1997 , between $46 \%$ and $60 \%$ were prescribed warfarin $[7,10,11]$; in earlier studies dating to the mid-1990s, only $17 \%$ to $32 \%$ received warfarin $[8,9]$. Our findings suggest that bleeding risk alone may not explain the low rates of warfarin use for AF in LTC. Even among candidates described as having high stroke risk and low 
Table 4 Warfarin management and monitoring

\begin{tabular}{|c|c|c|c|c|c|}
\hline Study & $\begin{array}{l}\text { Study objective, } \\
\text { (intervention/exposure } \\
\text { and outcomes) }\end{array}$ & $\begin{array}{l}\text { Study design, } \\
\text { data source }\end{array}$ & $\begin{array}{l}\text { Study population, } \\
\text { study setting, } \\
\text { time period }\end{array}$ & Results & $\begin{array}{l}\text { Quality assessment, } \\
\text { funding Source }\end{array}$ \\
\hline \multicolumn{6}{|c|}{ Part A: Quality of oral anticoagulant prescribing and monitoring } \\
\hline $\begin{array}{l}\text { Aspinall et al. } \\
\text { (2010) }[15,30]\end{array}$ & $\begin{array}{l}\text { To describe the quality of } \\
\text { warfarin prescribing and } \\
\text { monitoring in VA nursing } \\
\text { homes and to assess } \\
\text { factors associated with } \\
\text { maintaining a therapeutic } \\
\text { INR }\end{array}$ & $\begin{array}{l}\text { Design: } \\
\text { retrospective } \\
\text { cohort study } \\
\text { Data source: } \\
\text { medical record } \\
\text { review }\end{array}$ & $\begin{array}{l}\text { Population: all veterans (160) } \\
\text { who received warfarin } \\
\text { Setting: } 5 \text { VA nursing homes } \\
\text { (US) } \\
\text { Time period: } \\
\text { Jan 1, } 2008 \text { - June 30, } 2008\end{array}$ & $\begin{array}{l}\text { INRs were in therapeutic range for } 55 \% \text { of } \\
\text { the } 10,380 \text { total person-days of warfarin. In } \\
\text { a } 4 \text {-week period, patients had an average of } \\
5.2 \text { (SD = 2.7) INRs obtained. } 99 \% \text { of the INR } \\
\text { tests were repeated within } 4 \text { weeks of the } \\
\text { previous result. } 49 \% \text { of patients had INRs in } \\
\text { the target range for } \geq 50 \% \text { of their person- } \\
\text { days. Achieving this outcome was more } \\
\text { likely in patients with prevalent warfarin use } \\
\text { than with new use (adjusted OR }=2.86 \text {; } \\
95 \% \mathrm{Cl}=1.06-7.72) \text {. Patients with a history } \\
\text { of a stroke (adjusted OR = 50.38; } 95 \% \mathrm{Cl}= \\
50.18-0.80) \text { were less likely to have } \\
\text { therapeutic INRs for }>50 \% \text { of their days. } \\
\text { Approximately } 89 \% \text { of the patients at } \\
\text { baseline were receiving } \geq 1 \text { medication that } \\
\text { potentially interacts with warfarin. The most } \\
\text { frequently prescribed interacting drugs at } \\
\text { baseline were omeprazole (51\% of patients), } \\
\text { simvastatin (45\%), aspirin (34\%), citalopram } \\
\text { (18\%), and levothyroxine (13\%). During the } \\
\text { study period, } 46 \% \text { of patients were } \\
\text { prescribed a medication with the potential } \\
\text { to interact with warfarin }\end{array}$ & $\begin{array}{l}\text { Quality assessment } \\
\text { for observational studies: } \\
\text { 1) Unbiased selection of the cohort? Yes } \\
\text { 2) Selection minimizes baseline differences in } \\
\text { prognostic factors? Yes } \\
\text { 3) Sample size calculated/5\% difference? No } \\
\text { 4) Adequate description of the cohort? Yes } \\
\text { 5) Validated method for ascertaining exposure? Yes } \\
\text { 6) Validated method for ascertaining clinical } \\
\text { outcomes? Yes } \\
\text { 7) Outcome assessment blind to exposure? Yes } \\
\text { 8) Adequate follow-up period? Partial; length of } \\
\text { follow-up not clearly stated in Methodology } \\
\text { 9) Completeness of follow-up? Yes } \\
\text { 10) Analysis controls for confounding? Yes } \\
\text { 11) Analytic methods appropriate? Yes } \\
\text { Funding: various VA centers and US government } \\
\text { agencies }\end{array}$ \\
\hline $\begin{array}{l}\text { Gurwitz et al. } \\
\text { (2007) [25] } \\
\text { (repeated from } \\
\text { table 1) }\end{array}$ & & & & $\begin{array}{l}\text { The percentages of time in the }<2,2-3 \text {, } \\
\text { and }>3 \text { INR ranges were } 36.5 \%, 49.6 \% \text {, and } \\
13.9 \% \text {, respectively }\end{array}$ & \\
\hline $\begin{array}{l}\text { Gurwitz et al. } \\
\text { (1997) [8] } \\
\text { (repeated from } \\
\text { table 1) }\end{array}$ & & & & $\begin{array}{l}\text { Of } 122 \text { warfarin users with adequate INR } \\
\text { data, warfarin therapy was monitored at } \\
\text { least every } 2 \text { weeks in } 52 \% \text { of the subjects, } \\
\text { every } 2-4 \text { weeks in } 32 \% \text { of the subjects, and } \\
\text { less frequently than every } 4 \text { weeks in only } \\
16 \% \text { of the subjects. On average, } 117 \text { NVAF } \\
\text { residents with available INR data were } \\
\text { maintained in the therapeutic range } 39.6 \% \\
\text { of the time, in the subtherapeutic range } \\
44.8 \% \text { of the time, and in the } \\
\text { supratherapeutic range } 15.6 \% \text { of the time; < } \\
23 \text { subjects }(20 \% \text { ) were in the therapeutic } \\
\text { range } \geq 60 \% \text { of the time }\end{array}$ & \\
\hline
\end{tabular}


Table 4 Warfarin management and monitoring (Continued)

\begin{tabular}{|c|c|c|c|c|c|}
\hline $\begin{array}{l}\text { Karki et al. (2003) } \\
\text { [31] }\end{array}$ & $\begin{array}{l}\text { To evaluate the warfarin } \\
\text { management patterns in } \\
\text { an academic nursing } \\
\text { home and evaluate what } \\
\text { pre-determined factors } \\
\text { are associated with } \\
\text { variability in the INR }\end{array}$ & $\begin{array}{l}\text { Design: case } \\
\text { control study } \\
\text { Data source: } \\
\text { medical chart } \\
\text { review }\end{array}$ & $\begin{array}{l}\text { Population: } 37 \text { residents } \\
\text { receiving warfarin therapy for } \\
>3 \text { consecutive months in a } \\
\text { calendar year } \\
\text { Setting: } 566 \text {-bed academic } \\
\text { medical center nursing home } \\
\text { (US) } \\
\text { Time period: } 12 \text {-month period; } \\
\text { dates not specified }\end{array}$ & $\begin{array}{l}\text { For patients who had INR values exceeding } \\
\text { the therapeutic range there was no } \\
\text { significant difference between "easy" } \\
\text { management (INR fluctuations of } 0.5-0.99 \\
\text { and outside therapeutic range } \leq 10 \% \text { of } \\
\text { time, } n=18 \text { ) and "difficult" management } \\
\text { (with INR fluctuations }>0.99 \text { and outside } \\
\text { therapeutic range }>10 \% \text { of time, } n=19) \text { in } \\
\text { all factors examined. The "difficult } \\
\text { management" group received more } \\
\text { medications known to interact with warfarin } \\
\text { than the "easy" management. These } \\
\text { medications may have caused the INR to } \\
\text { increase above the normal range ( } P=0.003) \text {, } \\
\text { as well as produced large ( } P=0.001) \text { or small } \\
\text { fluctuations ( } P=0.0007) \text { in the INR. } 54 \% \text { of } \\
\text { residents on warfarin therapy initiated a } \\
\text { potential warfarin-interacting drug. Of all } \\
\text { interacting medications, } 55 \% \text { were } \\
\text { antibiotics and } 28 \% \text { were analgesics }\end{array}$ & $\begin{array}{l}\text { Quality assessment } \\
\text { for observational studies: } \\
\text { 1) Unbiased selection of the cohort? Partial; limited } \\
\text { to residents of a single nursing home } \\
\text { 2) Selection minimizes baseline differences in } \\
\text { prognostic factors? Yes } \\
\text { 3) Sample size calculated/5\% difference? No; very } \\
\text { low power } \\
\text { 4) Adequate description of the cohort? No; only } \\
\text { limited description of nursing home and resident } \\
\text { characteristics reported } \\
\text { 5) Validated method for ascertaining exposure? No; } \\
\text { assignment of subjects to "easy management" and } \\
\text { "difficult management" cohorts not validated } \\
\text { 6) Validated method for ascertaining clinical } \\
\text { outcomes? Yes } \\
\text { 7) Outcome assessment blind to exposure? Yes } \\
\text { 8) Adequate follow-up period? Yes } \\
\text { 9) Completeness of follow-up? Yes } \\
\text { 10) Analysis controls for confounding? Partial; } \\
\text { evaluated association of age, gender, and number } \\
\text { of illnesses with cohort } \\
\text { 11) Analytic methods appropriate? Partial; only } \\
\text { limited univariate analyses conducted } \\
\text { Funding: not stated }\end{array}$ \\
\hline $\begin{array}{l}\text { Lackner et al. } \\
\text { (1995)[9] (repeated } \\
\text { from table 1) }\end{array}$ & & & & $\begin{array}{l}\text { The INR was within the recommended } \\
\text { range for NVAF over a } 6 \text {-month period } 37 \% \\
\text { of the time and recommended PT, } 52 \% \text { of } \\
\text { the time. An equal percentage of warfarin } \\
\text { dose changes occurred in response to a PT } \\
\text { ratio outside the recommended range as } \\
\text { occurred with an INR outside the } \\
\text { recommended range }\end{array}$ & \\
\hline $\begin{array}{l}\text { McCormick et al. } \\
\text { (2001) [11] } \\
\text { (repeated from } \\
\text { table 1) }\end{array}$ & & & & $\begin{array}{l}\text { In the } 42 \% \text { of AF patients who were } \\
\text { receiving warfarin therapy, the therapeutic } \\
\text { range of INR values was maintained only } \\
51 \% \text { of the time, was below the therapeutic } \\
\text { range } 36 \% \text { of the time, and was above the } \\
\text { therapeutic range } 13 \% \text { of the time }\end{array}$ & \\
\hline
\end{tabular}




\begin{tabular}{|c|c|c|c|c|c|}
\hline $\begin{array}{l}\text { Verhovsek et al. } \\
\text { (2008) [22] }\end{array}$ & $\begin{array}{l}\text { To determine how } \\
\text { effectively warfarin was } \\
\text { administered to a cohort } \\
\text { of residents in LTC } \\
\text { facilities by measuring } \\
\text { TTR, to identify the } \\
\text { proportion of residents } \\
\text { prescribed warfarin- } \\
\text { interacting drugs and to } \\
\text { ascertain factors } \\
\text { associated with poor INR } \\
\text { control }\end{array}$ & $\begin{array}{l}\text { Design: } \\
\text { Retrospective } \\
\text { cohort study } \\
\text { Data source: } \\
\text { medical chart } \\
\text { review }\end{array}$ & $\begin{array}{l}\text { Population: } 105 \text { LTC residents } \\
\text { receiving warfarin therapy } \\
\text { Setting: } 5 \text { LTC facilities in } \\
\text { Hamilton, Ontario (Canada) } \\
\text { Time period: } 12 \text { months of } \\
\text { data for each resident } \\
\text { between October } 2004 \text { and } \\
\text { April } 2005\end{array}$ & $\begin{array}{l}3065 \text { INR values were available. Residents } \\
\text { were within, below, and above the } \\
\text { therapeutic range } 54 \%, 35 \% \text { and } 11 \% \text { of the } \\
\text { time, respectively. } 79 \% \text { of residents were } \\
\text { prescribed } \geq 1 \text { warfarin-interacting } \\
\text { medication during the period in review. The } \\
5 \text { most common drugs were } \\
\text { acetaminophen ( } 40 \% \text { of residents), } \\
\text { citalopram ( } 25 \%) \text {, acetylsalicylic acid (16\%), } \\
\text { diltiazem (11\%), and simvastatin ( } 10 \%) \text {. } \\
\text { Residents receiving interacting medications } \\
\text { spent less TTR (53.0\% vs } 58.2 \% \text {, OR = } 0.93 \text {; } \\
95 \% \mathrm{Cl}=0.88-0.97, P=0.002) \text {. Adequacy of } \\
\text { anticoagulation varied significantly between } \\
\text { physicians (TTR range } 45.9-63.9 \%)\end{array}$ & $\begin{array}{l}\text { Quality assessment } \\
\text { for observational studies: } \\
\text { 1) Unbiased selection of the cohort? Yes } \\
\text { 2) Selection minimizes baseline differences in } \\
\text { prognostic factors? Yes } \\
\text { 3) Sample size calculated/5\% difference? No; low } \\
\text { power for both residents and physicians studied } \\
\text { 4) Adequate description of the cohort? Yes } \\
\text { 5) Validated method for ascertaining exposure? Yes } \\
\text { 6) Validated method for ascertaining clinical } \\
\text { outcomes? Yes } \\
\text { 7) Outcome assessment blind to exposure? Yes } \\
\text { 8) Adequate follow-up period? Partial; some } \\
\text { residents may have had < } 6 \text { month follow-up of } \\
\text { INR } \\
\text { 9) Completeness of follow-up? Yes } \\
\text { 10) Analysis controls for confounding? No; } \\
\text { association of INR outcomes with subject attributes } \\
\text { not analyzed } \\
\text { 11) Analytic methods appropriate? No; analysis of } \\
\text { residents limited to simple one-way tabulations } \\
\text { Funding: CIHR and the Regional Medical Associates }\end{array}$ \\
\hline \multicolumn{6}{|c|}{ Part B: Medication management interventions } \\
\hline $\begin{array}{l}\text { Allen et al. (2000) } \\
\text { [23] }\end{array}$ & $\begin{array}{l}\text { To evaluate the } \\
\text { effectiveness of nurse } \\
\text { practitioner management } \\
\text { of anticoagulation using } \\
\text { a protocol. Outcomes } \\
\text { were frequency of blood } \\
\text { draws as well as } \\
\text { frequency and } \\
\text { percentage of INRs that } \\
\text { were out of range }\end{array}$ & $\begin{array}{l}\text { Design: } \\
\text { retrospective } \\
\text { cohort study } \\
\text { Data source: } \\
\text { nurse practitioner } \\
\text { maintained } \\
\text { records }\end{array}$ & $\begin{array}{l}\text { Population: } 47 \text { patients on } \\
\text { long-term anticoagulation } \\
\text { therapy } \\
\text { Setting: } 9 \text { area nursing homes } \\
\text { (US) } \\
\text { Time period: } 6 \text { months } \\
\text { beginning June } 1997\end{array}$ & $\begin{array}{l}\text { Average number of venipuncture ranged } \\
\text { from } 0.7-2.7 \text { per month. Reasons for out-of- } \\
\text { range INRs were identified } 35 \% \text { of the time. } \\
\text { Percentage out of range was } 15 \%\end{array}$ & $\begin{array}{l}\text { Quality assessment } \\
\text { for observational studies: } \\
\text { 1) Unbiased selection of the cohort? Cannot be } \\
\text { determined; convenience sample of } 47 \text { residents } \\
\text { 2) Selection minimizes baseline differences in } \\
\text { prognostic factors? Yes } \\
\text { 3) Sample size calculated/5\% difference? No } \\
\text { 4) Adequate description of the cohort? No; resident } \\
\text { characteristics not described } \\
\text { 5) Validated method for ascertaining exposure? Yes } \\
\text { 6) Validated method for ascertaining clinical } \\
\text { outcomes? Yes } \\
\text { 7) Outcome assessment blind to exposure? No } \\
\text { 8) Adequate follow-up period? Cannot be } \\
\text { determined; post-intervention follow-up period not } \\
\text { described } \\
\text { 9) Completeness of follow-up? Cannot be } \\
\text { determined } \\
\text { 10) Analysis controls for confounding? No; no } \\
\text { evaluation of association of resident attributes with } \\
\text { INR outcomes } \\
\text { 11) Analytic methods appropriate? No; Statistical } \\
\text { error not reported } \\
\text { Funding: not specified }\end{array}$ \\
\hline
\end{tabular}


Table 4 Warfarin management and monitoring (Continued)

\begin{tabular}{|c|c|}
\hline $\begin{array}{l}\text { Papaioannou et al. } \\
\text { (2010) [24] } \\
\text { (repeated from } \\
\text { Table 1) }\end{array}$ & $\begin{array}{l}\text { Overall, TTR increased during the MEDeINR } \\
\text { phase }(65-69 \%) \text {, but was significantly } \\
\text { increased for only } 1 \text { facility ( } 62-71 \%, P< \\
\text { 0.05). The percentage of time in } \\
\text { supratherapeutic range decreased from } 14 \% \\
\text { to } 11 \%, P=0.08) \text {; there was little change for } \\
\text { the subtherapeutic range ( } 21 \% \text { to } 20 \% \text {, } \\
P=0.66) \text {. Overall, the average number of INR } \\
\text { tests per } 30 \text { days decreased from } 4.2 \text { to } 3.1 \\
(P<0.0001) \text { per resident post- } \\
\text { implementation. Feedback from LTC } \\
\text { clinicians and staff indicated that the } \\
\text { program decreased workload, improved } \\
\text { confidence in management and decisions, } \\
\text { and was generally easy to use }\end{array}$ \\
\hline
\end{tabular}

Cl, confidence interval; CIHR, Canadian Institute of Health Research; INR, international normalized ratio; LTC, long-term care; NVAF, nonvalvular atrial fibrillation; OR, odds ratio; PT, prothrombin time; SD, standard deviation; TRR, time in therapeutic range; VA, Veteran's Administration 
Table 5 Warfarin-related adverse events

\begin{tabular}{|c|c|c|c|c|c|}
\hline Study & $\begin{array}{l}\text { Study } \\
\text { objective, } \\
\text { (intervention/ } \\
\text { exposure and } \\
\text { outcomes) }\end{array}$ & $\begin{array}{l}\text { Study design, data } \\
\text { source }\end{array}$ & $\begin{array}{l}\text { Study population, study } \\
\text { setting, time period }\end{array}$ & Results & $\begin{array}{l}\text { Quality assessment, } \\
\text { funding source }\end{array}$ \\
\hline $\begin{array}{l}\text { Gurwitz et al. } \\
\text { (2007) [25] } \\
\text { (repeated from } \\
\text { Table 1) }\end{array}$ & & & & $\begin{array}{l}720 \text { warfarin-related AEs and } 253 \text { potential warfarin-related AEs were } \\
\text { identified. Of the warfarin-related AEs, } 87 \% \text { were characterized as minor, } \\
11 \% \text { were deemed serious, and } 2 \% \text { were life-threatening or fatal. Overall, } \\
29 \% \text { of warfarin-related AEs were judged to be preventable. The rate of } \\
\text { warfarin-related AEs was } 18.8 \text { per } 100 \text { resident-months on warfarin } \\
\text { therapy ( } 95 \% \mathrm{Cl}, 17.5-20.3 \text { per } 100 \text { resident-months), with a rate of } 5.4 \\
\text { preventable warfarin-related AEs per } 100 \text { resident-months ( } 95 \% \mathrm{Cl}, 4.7-6.2 \\
\text { per } 100 \text { resident-months). Potential warfarin-related AEs occurred at a rate } \\
\text { of } 6.6 \text { per } 100 \text { resident-months on warfarin ( } 95 \% \mathrm{Cl} \text {, } 5.8-7.5 \text { per } 100 \\
\text { resident-months). Serious, life-threatening, or fatal events occurred at a } \\
\text { rate of } 2.5 \text { per } 100 \text { resident-months ( } 95 \% \mathrm{Cl}, 2.0-3.0 \text { per } 100 \text { resident- } \\
\text { months); } 57 \% \text { of these more severe AEs were considered preventable. } \\
\text { Errors resulting in preventable AEs occurred most often at the prescribing } \\
\text { and monitoring stages of warfarin management }\end{array}$ & \\
\hline $\begin{array}{l}\text { Quilliam et al. } \\
\text { (2001) [26] }\end{array}$ & $\begin{array}{l}\text { To quantify } \\
\text { the effect of } \\
\text { antiplatelet } \\
\text { and } \\
\text { anticoagulant } \\
\text { agents on risk } \\
\text { of } \\
\text { hospitalization } \\
\text { for bleeding } \\
\text { among an } \\
\text { elderly nursing } \\
\text { home stroke } \\
\text { survivors }\end{array}$ & $\begin{array}{l}\text { Design: case- control } \\
\text { study } \\
\text { Data source: } \\
\text { Medicare claims and } \\
\text { MDS assessments in } \\
\text { the SAGE database }\end{array}$ & $\begin{array}{l}\text { Population: nursing home } \\
\text { residents, } 3433 \text { cases (residents } \\
\text { with first hospitalization for } \\
\text { bleeds) and } 13,506 \text { controls } \\
\text { (residents having no such } \\
\text { hospitalizations) } \\
\text { Setting: nursing homes in5 states } \\
\text { (US) } \\
\text { Time period: 1992-1997 }\end{array}$ & 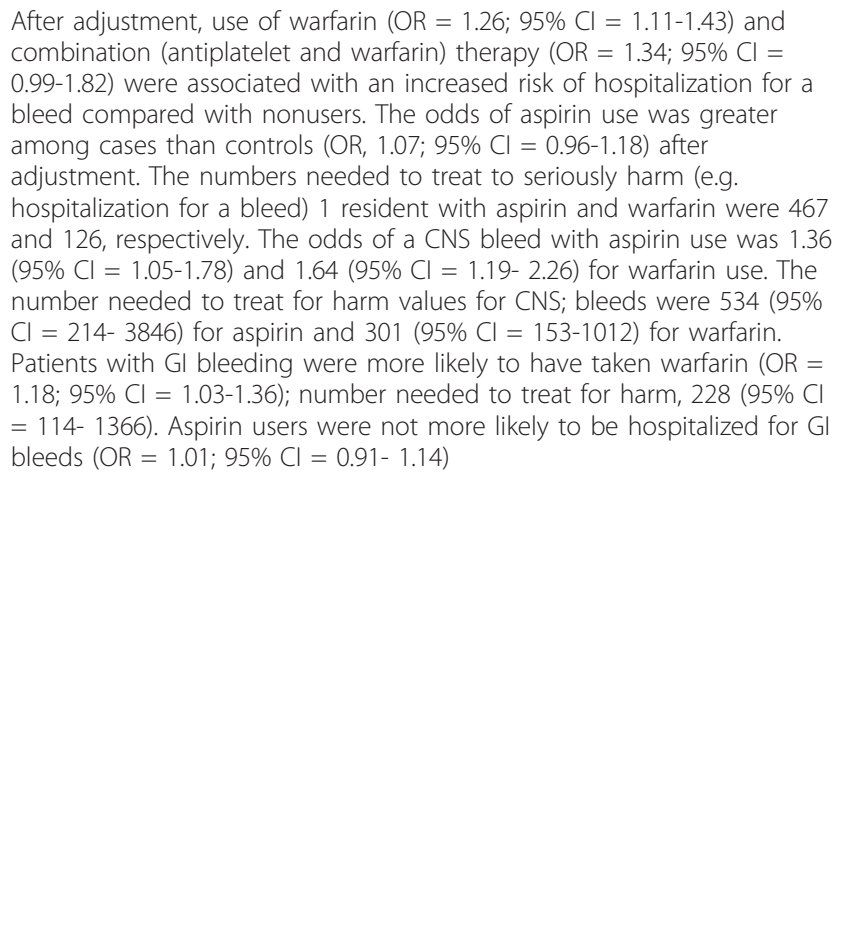 & $\begin{array}{l}\text { Quality assessment for } \\
\text { observational studies: } \\
\text { 1) Unbiased selection of } \\
\text { the cohort? Yes } \\
\text { 2) Selection minimizes } \\
\text { baseline differences in } \\
\text { prognostic factors? Yes } \\
\text { 3) Sample size } \\
\text { calculated/5\% difference? } \\
\text { Yes } \\
\text { 4) Adequate description } \\
\text { of the cohort? Yes } \\
\text { 5) Validated method for } \\
\text { ascertaining exposure? } \\
\text { Yes } \\
\text { 6) Validated method for } \\
\text { ascertaining clinical } \\
\text { outcomes? Yes } \\
\text { 7) Outcome assessment } \\
\text { blind to exposure? Yes } \\
\text { 8) Adequate follow-up } \\
\text { period? Yes; cross- } \\
\text { sectional } \\
\text { 9) Completeness of } \\
\text { follow-up? Yes } \\
\text { 10) Analysis controls for } \\
\text { confounding? Yes } \\
\text { 11) Analytic methods } \\
\text { appropriate? Yes } \\
\text { Funding: AHRQ }\end{array}$ \\
\hline
\end{tabular}


bleeding risk, rates of warfarin use among LTC residents with AF in three studies were 20\% [10], 53\% [11], and $60 \%[10]$.

\section{Physician concerns illustrate resistance to using warfarin} Physician concerns may, in part, explain low observed warfarin use in the LTC setting. Surveys of physicians using case-study examples showed that respondents strongly supported use of antiplatelet agents [27]. However, these same respondents appeared reluctant to prescribe warfarin for the case-study residents, each of whom had AF plus one or more major risk factors for stroke. Only half of surveyed physicians agreed that benefits of warfarin therapy greatly outweigh the risks [29]. Specific concerns motivating physicians to avoid using warfarin seem clear, starting with risk of falls in two studies $(71 \%$ and 98\%) [26,28], and including dementia [27], short life expectancy [27], history of GI bleeding [29], history of other non-CNS bleeding [29], and history of cerebrovascular hemorrhage [29].

\section{Consensus noted among some factors associated with use of warfarin}

In this review, several factors were associated with greater use of stroke prevention therapy-AF in stroke survivors $[12,18]$, history of stroke $[7,8]$ in residents with AF, hypertension $[12,18]$ in stroke survivors, and depression $[12,18]$ in stroke survivors. Dementia and severe cognitive impairment were generally associated with lower use or initiation of stroke prevention therapy in LTC $[8,12,18]$. Previous GI bleeding was also strongly and negatively linked to use of warfarin or antiplatelets in patients with AF and in stroke survivors $[7,12]$.

This review also found that black race was generally associated with lower, adjusted use of therapy. Although one study [7] did not find a significant multivariate association between African-American race and use of warfarin or antiplatelets in stroke survivors, the number of observed subjects $(\mathrm{n}=117)$ may have been too small to adequately test this factor. Three other studies $[12,17,18]$ that examined the same therapies in strongly powered multivariate models found evidence of a significantly lower use of these agents among black compared with white stroke survivors.

Conflicting findings or no evidence of association were found across studies for other resident characteristics and use of stroke prevention therapy: age $\geq 85$ years (reduction or no association), coronary artery disease (increase or no association), dependent physical functioning (reduction or no association), peptic ulcer disease (reduction or no association), high overall bleeding risk (reduction or no association), and overall stroke risk (no association).
Warfarin management and monitoring signal that INR levels remain difficult to maintain

Studies in this review consistently showed that in LTC residents receiving warfarin, INRs are in the target range approximately half of the time $[8,9,11,22,25,30]$. With further evidence that only one in five residents exceed $60 \%$ of monitored time in therapeutic range [8], achieving INR targets is a potentially serious problem in the LTC setting. Comparing mean values reported in this review, residents who fall out of target range are 2.5-3 times more likely to have INR levels that are subtherapeutic, which exposes them to a potentially greater risk of stroke, rather than supratherapeutic, which would increase their bleeding risk. Studies in this review suggest that blood draws in LTC occur frequently $[8,30]$, at least once per month for $84 \%$ or more of residents $[8,30]$, and more often for many residents $[23,24]$. McCormick et al. [11] discuss the seeming paradox in the controlled-care environment of LTC where such INR control problems often occur. Although non-adherence to medication or INR monitoring poses fewer problems in the LTC setting, and despite potentially better control of interacting medications and diet, warfarin prescribing and INR monitoring appear less than optimal [11].

Several factors may be associated with reduced time in INR therapeutic range. These include history of stroke [30] and medication interactions [22,31]. Regarding the latter, evidence from this review suggests that the opportunity for warfarin interactions in the LTC facility is great, with $46-89 \%[22,30,31]$ of residents taking a potentially interacting medication.

The two studies that evaluated medication management systems $[23,24]$ reported substantially higher postintervention times in target range than those discussed above. However, in one of these studies [24], the use of an electronic decision support system for warfarin dosing produced no significant gain across facilities in timein-range when compared to the pre-intervention period. Findings from the second study [23] showed that $85 \%$ of post-intervention INR draws were within range; however, these results are largely uninterpretable, since the study lacked pre-intervention data or a separate control group.

Although no study to date has established a link between poor INR control and health outcomes in LTC, warfarin-related adverse events are common in the LTC facility: the combined overall rate of adverse warfarinrelated events and potential adverse warfarin-related events was high, equivalent to one adverse effect for every 4 months on therapy [25]. The use of warfarin was also associated with a significantly increased risk of hospitalization for a bleeding event [26]. 


\section{Conclusions}

Consensus guidelines regarding the use of warfarin for primary or secondary stroke prevention in AF may not be sufficiently followed in the LTC setting, where warfarin use appears suboptimal. The challenges of warfarin use in the LTC setting are apparent to physicians and, in their view, may outweigh the benefits of stroke risk reduction. For LTC residents who are receiving warfarin, maintaining therapeutic INR remains problematic, even in the highly controlled LTC environment. Further research is needed to evaluate appropriate use of anticoagulants in this setting, including a more explicated consideration of the appropriate balancing of risks and benefits in an important but problematic issue for the geriatric clinician.

\section{Acknowledgements \\ The current study was sponsored by Janssen Scientific Affairs, LLC. The involvement of the study sponsor in the collection, analysis, and interpretation of data; in the writing of the manuscript; and in the decision to submit the manuscript for publication was limited to the contribution, as noted above, of two coauthors (AAP and WWN), who were employees and stockholders of the study sponsor. MN and GR received compensation for their work in conducting the literature review and for manuscript production. The authors would like to acknowledge Ruth Sussman, PhD, who provided editorial review of this author-prepared manuscript, whose work was supported with funding from the study sponsor.}

\section{Author details}

'Informagenics, LLC, 450 W. Wilson Bridge Rd., Suite 340, Worthington, $\mathrm{OH}$ 43085, USA. ${ }^{2}$ The Ohio State University College of Pharmacy, Columbus, OH, USA. ${ }^{3}$ Janssen Scientific Affairs, LLC, Raritan, NJ, USA.

\section{Authors' contributions}

Coauthors' contributions to this manuscript include the following: MN (study design, article search and summarization, table production, analysis, manuscript production), AAP (initial study concept, study design, manuscript rewrite), WWN (study design, critical review, manuscript rewrite), GR (study design, article search and summarization, table production, analysis, manuscript production). All authors read and approved the final manuscript.

\section{Competing interests}

AAP and WWN are employees of Janssen Scientific Affairs, LLC (a Johnson and Johnson company) and shareholders of Johnson and Johnson. At the time this research was conducted, MN and GR were consultants to Janssen Scientific Affairs, LLC and received funding for this research and writing of the review manuscript. Janssen Scientific Affairs, LLC separately provided financial support for editing services and for the article processing charge associated with this author-prepared manuscript. Over the past five years GR also received funding from Pfizer Inc. for contracted research and services and development of other manuscripts. The authors declare no other financial or non-financial competing interests.

Received: 26 August 2011 Accepted: 5 April 2012

Published: 5 April 2012

\section{References}

1. Anon: 2001 Annual Report of the Board of Trustees of the Federal Old-Age and Survivors Insurance and Disability Insurance Trust Funds Washington, DC: Office of the Chief Actuary, Social Security Administration; 2001.

2. American Medical Directors Association: Stroke Management in the LongTermCare Setting Clinical Practice Guideline. Columbia (MD): AMDA; 2011:2011:42.

3. Beyth RJ, Quinn LM, Landefeld CS: Prospective evaluation of an index for predicting the risk of major bleeding in outpatients treated with warfarin. Am J Med 1998, 105(2):91-99.
4. DiMarco JP, Flaker G, Waldo AL, Corley SD, Greene HL, Safford RE, Rosenfeld LE, Mitrani G, Nemeth M: Factors affecting bleeding risk during anticoagulant therapy in patients with atrial fibrillation: observations from the Atrial Fibrillation Follow-up Investigation of Rhythm Management (AFFIRM) study. Am Heart J 2005, 149(4):650-656.

5. Hylek EM, Evans-Molina C, Shea C, Henault LE, Regan S: Major hemorrhage and tolerability of warfarin in the first year of therapy among elderly patients with atrial fibrillation. Circulation 2007, 115(21):2689-2696.

6. Poli D, Antonucci E, Grifoni E, Abbate R, Gensini GF, Prisco D: Bleeding risk during oral anticoagulation in atrial fibrillation patients older than 80 years. J Am Coll Cardiol 2009, 54(11):999-1002.

7. Abdel-Latif AK, Peng X, Messinger-Rapport BJ: Predictors of anticoagulation prescription in nursing home residents with atrial fibrillation. J Am Med Dir Assoc 2005, 6(2):128-131.

8. Gurwitz JH, Monette J, Rochon PA, Eckler MA, Avorn J: Atrial fibrillation and stroke prevention with warfarin in the long-term care setting. Arch Intern Med 1997, 157(9):978-984.

9. Lackner $T E$, Battis $G N$ : Use of warfarin for nonvalvular atrial fibrillation in nursing home patients. Arch Fam Med 1995, 4(12):1017-1026.

10. Lau E, Bungard TJ, Tsuyuki RT: Stroke prophylaxis in institutionalized elderly patients with atrial fibrillation. J Am Geriatr Soc 2004, 52(3):428-433.

11. McCormick D, Gurwitz JH, Goldberg RJ, Becker R, Tate JP, Elwell A, Radford MJ: Prevalence and quality of warfarin use for patients with atrial fibrillation in the long-term care setting. Arch Intern Med 2001, 161(20):2458-2463.

12. Quilliam BJ, Lapane KL: Clinical correlates and drug treatment of residents with stroke in long-term care. Stroke 2001, 32(6):1385-1393.

13. Sloane PD, Gruber-Baldini AL, Zimmerman S, Roth M, Watson L, Boustani M, Magaziner J, Hebel JR: Medication undertreatment in assisted living settings. Arch Intern Med 2004, 164(18):2031-2037.

14. Cheng $\mathrm{H}$ : Why health care providers don't prescribe warfarin to a frail nursing home resident with atrial fibrillation. J Am Med Dir Assoc 2006, 7(5):334-335

15. Torn M, Bollen WL, van der Meer FJ, van der Wall EE, Rosendaal FR: Risks of oral anticoagulant therapy with increasing age. Arch Intern Med 2005, 165(13):1527-1532.

16. Williams JW, Plassman BL, Burke J, Holsinger T, Benjamin S: Preventing Alzheimer's Disease and Cognitive Decline. Evidence Report/Technology Assessment No. 193. (Prepared by the Duke University Evidence-based Practice Center under Contract No. HHSA 290-2007-10066-I).Edited by: Quality AfHRa. Rockville, MD: Agency for Healthcare Research and Quality; 2010:

17. Christian JB, Lapane KL, Toppa RS: Racial disparities in receipt of secondary stroke prevention agents among US nursing home residents. Stroke 2003, 34(11):2693-2697.

18. Hughes CM, Lapane KL: Factors associated with the initiation and discontinuation of secondary stroke prevention agents in nursing homes. J Stroke Cerebrovasc Dis 2004, 13(4):164-170.

19. Lapane KL, Hughes CM: Did the introduction of a prospective payment system for nursing home stays reduce the likelihood of pharmacological management of secondary ischaemic stroke? Drugs Aging 2006, 23(1):61-69.

20. Crotty M, Whitehead C, Rowett D, Halbert J, Weller D, Finucane P, Esterman A: An outreach intervention to implement evidence based practice in residential care: a randomized controlled trial [ISRCTN67855475]. BMC Health Serv Res 2004, 4(1):6.

21. Horning KK, Hoehns JD, Doucette WR: Adherence to clinical practice guidelines for 7 chronic conditions in long-term-care patients who received pharmacist disease management services versus traditional drug regimen review. J Manag Care Pharm 2007, 13(1):28-36.

22. Verhovsek M, Motlagh B, Crowther MA, Kennedy C, Dolovich L, Campbell G, Wang L, Papaioannou A: Quality of anticoagulation and use of warfarininteracting medications in long-term care: a chart review. BMC Geriatr 2008, 8:13.

23. Allen LA, Mihalovic SJ, Narveson GG: Successful protocol-based nurse practitioner management of warfarin anticoagulation in nursing home patients. Ann Long Term Care 2000, 8(3):60-64.

24. Papaioannou A, Kennedy CC, Campbell G, Stroud JB, Wang L, Dolovich L, Crowther MA: A team-based approach to warfarin management in long 
term care: A feasibility study of the MEDeINR electronic decision support system. BMC Geriatr 2010, 10:38.

25. Gurwitz JH, Field TS, Radford MJ, Harrold LR, Becker R, Reed G, DeBellis K, Moldoff J, Verzier $\mathrm{N}$ : The safety of warfarin therapy in the nursing home setting. Am J Med 2007, 120(6):539-544.

26. Quilliam BJ, Lapane KL, Eaton CB, Mor V: Effect of antiplatelet and anticoagulant agents on risk of hospitalization for bleeding among a population of elderly nursing home stroke survivors. Stroke 2001, 32(10):2299-2304.

27. Dharmarajan TS, Varma S, Akkaladevi S, Lebelt AS, Norkus EP: To anticoagulate or not to anticoagulate? A common dilemma for the provider: physicians' opinion poll based on a case study of an older long-term care facility resident with dementia and atrial fibrillation. J Am Med Dir Assoc 2006, 7(1):23-28.

28. Harrold LR, Gurwitz JH, Tate JP, Becker R, Stuart T, Elwell A, Radford M: Physician attitudes concerning anticoagulation services in the long-term care setting. J Thromb Thrombolysis 2002, 14(1):59-64.

29. Monette J, Gurwitz JH, Rochon PA, Avorn J: Physician attitudes concerning warfarin for stroke prevention in atrial fibrillation: results of a survey of long-term care practitioners. J Am Geriatr Soc 1997, 45(9):1060-1065.

30. Aspinall SL, Zhao X, Handler SM, Stone RA, Kosmoski JC, Libby EA, Francis SD, Goodman DA, Roman RD, Bieber HL, et al: The quality of warfarin prescribing and monitoring in Veterans Affairs nursing homes. J Am Geriatr Soc 2010, 58(8):1475-1480.

31. Karki SD, Lander SM: Evaluation of anticoagulation therapy in an academic nursing home. J Pharm Technol 2003, 19(3):141-145.

32. Geerts WH, Bergqvist D, Pineo GF, Heit JA, Samama CM, Lassen MR, Colwell CW: Prevention of venous thromboembolism: American College of Chest Physicians Evidence-Based Clinical Practice Guidelines (8th Edition). Chest 2008, 133(6 Suppl):381S-453S.

33. Kearon C, Kahn SR, Agnelli G, Goldhaber S, Raskob GE, Comerota AJ: Antithrombotic therapy for venous thromboembolic disease: American College of Chest Physicians Evidence-Based Clinical Practice Guidelines (8th Edition). Chest 2008, 133(6 Suppl):454S-545S.

34. Singer DE, Albers GW, Dalen JE, Fang MC, Go AS, Halperin JL, Lip GY, Manning WJ: Antithrombotic therapy in atrial fibrillation: American College of Chest Physicians Evidence-Based Clinical Practice Guidelines (8th Edition). Chest 2008, 133 (6 Suppl):546S-592S.

35. Fuster V, Ryden LE, Cannom DS, Crijns HJ, Curtis AB, Ellenbogen KA, Halperin JL, Le Heuzey JY, Kay GN, Lowe JE, et al: ACC/AHA/ESC 2006 Guidelines for the Management of Patients with Atrial Fibrillation: a report of the American College of Cardiology/American Heart Association Task Force on Practice Guidelines and the European Society of Cardiology Committee for Practice Guidelines (Writing Committee to Revise the 2001 Guidelines for the Management of Patients With Atrial Fibrillation): developed in collaboration with the European Heart Rhythm Association and the Heart Rhythm Society. Circulation 2006, 114(7):e257-354

36. Camm AJ, Kirchhof P, Lip GY, Schotten U, Savelieva I, Ernst S, Van Gelder IC, Al-Attar N, Hindricks G, Prendergast B, et al: Guidelines for the management of atrial fibrillation: the Task Force for the Management of Atrial Fibrillation of the European Society of Cardiology (ESC). Eur Heart $\rfloor$ 2010, 31(19):2369-2429.

\section{Pre-publication history}

The pre-publication history for this paper can be accessed here: http://www.biomedcentral.com/1471-2318/12/14/prepub

doi:10.1186/1471-2318-12-14

Cite this article as: Neidecker et al:: Use of warfarin in long-term care: a systematic review. BMC Geriatrics 2012 12:14.

\section{Submit your next manuscript to BioMed Central and take full advantage of:}

- Convenient online submission

- Thorough peer review

- No space constraints or color figure charges

- Immediate publication on acceptance

- Inclusion in PubMed, CAS, Scopus and Google Scholar

- Research which is freely available for redistribution

Submit your manuscript at www.biomedcentral.com/submit
Biomed Central 